\title{
World agricultural convergence
}

\author{
Lingran Yuan ${ }^{1} \cdot$ Shurui Zhang ${ }^{1} \cdot$ Shuo Wang ${ }^{1} \cdot$ Zesen $_{\text {Qian }}{ }^{2} \cdot$ Binlei Gong $\mathbb{D}^{1,3,4}$ \\ Accepted: 26 February 2021 / Published online: 26 March 2021 \\ (c) The Author(s), under exclusive licence to Springer Science+Business Media, LLC, part of Springer Nature 2021
}

\begin{abstract}
The goal of this article is to answer two questions: Has world agricultural convergence occurred? If not, how can this goal be fulfilled? This article introduces a model averaging method to consider both a parametric and a semi-parametric SFA model to better estimate technical efficiency. Then, three types of convergence tests are employed to check if world agricultural catch-up occurs and to determine the degree of convergence across different groups of countries. The empirical results on a balanced panel of 126 countries from 1970-2014 show that world agricultural convergence has not occurred. This article then investigates the situations in different groups of countries and discusses how to use international trade, irrigation system, and structural transformation to improve agricultural efficiency and to diminish the efficiency gap among different countries in the future.
\end{abstract}

Keywords World Agricultural Convergence $\cdot$ Productivity and Efficiency $\cdot$ Stochastic Frontier Analysis $\cdot$ Convergence Tests $•$ Regional Catch-up

JEL Classification $\mathrm{O} 47 \cdot \mathrm{O} 13 \cdot \mathrm{D} 24 \cdot \mathrm{Q} 10 \cdot \mathrm{E} 23$

\section{Introduction}

Agriculture plays a fundamental role in human history. Prior to the Industrial Revolution, agriculture was the major economic activity and enabled the human population to grow. As a result, agricultural growth has been regarded as an essential condition, or even a precondition, for the rise of human civilization. Although the share of agriculture in total GDP kept decreasing, agriculture is still important after

These authors contributed equally: Lingran Yuan, Shurui Zhang, Shuo Wang, Zesen Qian, Binlei Gong

Binlei Gong

gongbinlei@zju.edu.cn

1 Department of Agricultural Economics and Management, School of Public Affairs, Zhejiang University, Hangzhou, China

2 School of Economics, Zhejiang University, Hangzhou, China

3 Academy of Social Governance, Zhejiang University, Hangzhou, China

4 Academy of Social Governance, China Academy for Rural Development, Zhejiang University, Hangzhou, China the Industrial Revolution. On the one hand, agriculture remains a vital and unique instrument for achieving poverty alleviation, especially in the rural areas (Thirtle et al. 2003; World Bank 2007; Chen and Gong 2021). On the other hand, agriculture has significant impacts on industrialization, urbanization, and the long-term evolution of the economy (Ashraf and Galor 2011; Carillo 2018). Some scholars (e.g., Lewis (1954), Ranis and Fei (1961), Foster and Rosenzweig (1996), Bustos et al. (2016), and Schmidt et al. (2018)) believe that higher agricultural productivity can enhance human capital accumulation, reallocate labor and other resource towards the industrial sector, and therefore stimulate the process of economic development. Other scholars (e.g., Matsuyama (1992), Foster and Rosenzweig (2004), Galor and Mountford (2008)), however, highlight that agricultural productivity growth may foster the comparative advantage of the agricultural sector, limit human capital formation, and hinder industrialization, especially in an open economy. To summarize, agriculture has always been a key determinant of economic growth.

To investigate the relationship between changes in agricultural productivity and long-run economic growth (in both agricultural and industrial sector), accurate estimation of agricultural productivity is necessary and therefore has 
been the subject of intensive research since the 1950s (Coelli and Rao 2005). Ruttan (2002) divides the comparative research on agricultural productivity growth into three stages. In the first two stages, efforts were directed towards measuring the single/partial factor productivity and then total factor productivity (TFP) (e.g., Kögel and Prskawetz (2001), Jin et al. (2002), O'Rourke and Williamson (2005), Strulik and Weisdorf (2008), Jin and Deininger (2009), Vollrath (2011), Yu (2012), and Gong et al. (2021)), whereas agricultural convergence tests in productivity and efficiency are the core of the third and current stage. Examining the evidence and rate that agricultural productivity is converging across countries is an issue of enduring interest, and for good reason: It indicates whether poor countries are catching up with rich countries (Henderson and Russell 2005) and clarifies the conditions under which nations benefit from an "backwardness advantage" to help design relevant development policies (Inklaar and Diewert 2016). Moreover, it can reflect the changes in comparative advantages of agriculture across countries and hence affect the structural transformation as well as the demographic transition.

The frontier productivity approach, including stochastic frontier analysis (SFA) and data envelopment analysis (DEA), is the most frequently used method in this line of research (Ruttan 2002; Coelli and Rao 2005). Compared with the classic production function method, this frontier approach allows for the further decomposition of productivity growth into shifts in the world frontier as well as changes in technical efficiency (Alene and Coulibaly 2009). In a seminal work of Kumar and Russell (2002), technical efficiency improvement is labeled as a technological catchup and indicates convergence, since it measures countries' movements toward the best global practice, or production frontier.

Some studies (e.g., Coelli and Rao (2005) and Rezitis (2010)) on agricultural productivity have employed the DEA approach to measure agricultural TFP/efficiency and test agricultural convergence. However, recent studies have found that agricultural productivity estimates using the DEA method often yields anomalous results (Headey et al. 2010). Nin et al. (2003) find that DEA-based TFP estimates typically lead to very different results when compared with those generated by every other measure of agricultural development, because DEA fails to distinguish productivity from measurement error and white noise. Different from many other industries, white noise and measurement error are significant challenges and problems in agricultural productivity analysis. On the one hand, agriculture is sensitive to and severely affected by certain difficult-to-observe shocks (e.g., changes in policies and prices, diseases and pests, as well as rainfall and temperature). On the other hand, agricultural data from Food and Agriculture
Organization of the United Nations (FAO), the main data sources for this line of study, can be deeply flawed, especially for small and poor nations without adequate capacity for statistical collection (Headey et al. 2010). Neither of these problems can be fully addressed in DEA, as it is a deterministic approach.

Stochastic frontier analysis, however, can capture measurement error and white noises in the disturbance, and therefore rules them out from the productivity estimates. Using both the DEA and SFA approaches on FAO data, Coelli et al. (2004) and Headey et al. (2010) find that SFA results are considerably more stable and credible than DEA results. However, most of these SFA studies (e.g., Kumbhakar and Wang (2005), Deliktas and Balcilar (2005), and Headey et al. (2010)) use the Battese and Coelli estimator (BC, hereafter), which is proposed by Battese and Coelli (1992) and has a similar monotonicity restriction on technical efficiency for all countries. As a result, BC92 fails to reflect the non-monotonic fluctuation in efficiencies across countries and over time. For example, the Green Revolution was introduced to various countries in different periods and the achievements in agricultural catch-up differed across countries and over time. In recent years, many new SFA models (e.g., Greene (2005), Greene (2008), Wang and Ho (2010), Kneip et al. (2012), and Kumbhakar et al. (2014)) are constantly developed to allow more flexible trend of efficiencies. To our knowledge, however, less effort has been made to apply these new models to test world convergence in agricultural efficiency. Therefore, the first puzzle is to find appropriate SFA estimators that can better capture the heterogeneity in country-level efficiency trend of agriculture.

Once the technical efficiencies are estimated, the next question is how to investigate convergence. Existing convergence tests include $\sigma$-convergence test, unconditional $\beta$ convergence test and conditional $\beta$-convergence test (Cameron et al. 2005; Madsen 2007; Ruan et al. 2008; Inklaar and Diewert 2016). Moreover, the degrees of convergence in different regions and different groups of countries are of great importance. Finally, how to improve technical efficiency and hence accelerate the speed of convergence is also a question of enduring interest in development economics.

This article aims to answer all of the questions mentioned above, especially those related to estimating accurate technical efficiency and investigating whether agricultural convergence occurs. Firstly, a Jackknife model averaging method is applied in this article, which can consider both a parametric and a semi-parametric SFA model to better estimate technical efficiency. Then, the aforementioned convergence tests are employed to determine whether world agricultural catch-up occurred as well as the degree of convergence among different 
groups of countries. It is worth noting that efficiency convergence only indicates that countries in the same group are becoming closer and closer, which can be either "good" or "bad". 'Similarly, efficiency divergence only indicates that countries in the same group are becoming more dispersed, which can also be "good" or "bad". Therefore, this article further investigates the heterogeneity in efficiency convergence and divergence, respectively. Finally, this article analyzes potential methods to improve agricultural efficiency and diminish the productivity gap among different groups of countries.

This study mainly contributes to the literature on agricultural convergence in three ways: (1) it tests not only the world agricultural convergence, but also the situations in different groups of countries; (2) it further analyzes how to accelerate technological catch-up in different countries and finds that the different major driving forces to achieve convergence within rich countries and poor countries; and (3) compared with existing efficiency convergence analyses, it further estimates technological progress to investigate the heterogeneity in efficiency convergence and divergence, respectively. Utilizing a balanced panel of 126 countries from 1970-2014, the empirical results show that world agricultural convergence has not occurred. This article then investigates the situations in different groups of countries and discusses how to use international trade, irrigation system, and structural transformation to improve agricultural efficiency and to diminish the efficiency gap among different countries in the future.

The rest of the paper is organized as follows: Section 2 establishes the model, Section 3 provides data description, Section 4 presents the empirical results and makes some discussions, and Section 5 concludes the paper.

\section{Model}

This section begins with an introduction to stochastic frontier model and how different models can be combined to estimate efficiency. Then three types of convergence tests are established to measure agricultural efficiency convergence. Finally, endogeneity problems are discussed.

\subsection{Stochastic frontier analysis}

Productivity This article adopts stochastic frontier analysis (SFA) to estimate technical efficiency, which has been used in some studies (e.g., Jin et al. 2010, Wang et al. 2016,

\footnotetext{
1 A "good" convergence occurs when the leading countries experience normal or fast technological progress whereas the lagging countries grow even very fast. A "bad" convergence occurs, on the other hand, when the lagging countries grow slowly but the leading countries grow slower or even experience stagnation.
}

Ma et al. 2019, and Gong and Sickles 2020) to measure the productivity gap. It is worth noting that the DEA also has its own advantages, as it does not need to impose assumptions of parametric functional forms and distributional assumptions on random noise and inefficiency as in the SFA. However, measurement errors may be pertinent in the USDA-ERS dataset (Alston and Pardey 2014), which is employed in this article. Since flexibility is less important than measurement errors in this particular application, we choose to use the SFA. The classic SFA model with the Cobb-Douglas formation was first proposed by Aigner et al. (1977) and Meeusen and Van den Broeck (1977), then developed by Schmidt and Sickles (1984) under a panel data setting,

$$
\begin{gathered}
y_{i t}=f\left(X_{i t}\right)-u_{i}+\nu_{i t}=\alpha+\sum_{k=1}^{K} \beta^{k} x_{i t}^{k}-u_{i}+\nu_{i t} \\
=\alpha_{i}+\sum_{k=1}^{K} \beta^{k} x_{i t}^{k}+\nu_{i t},
\end{gathered}
$$

where $y_{i t}$ is the output of country $i$ at time $t$ in logarithms, and $x_{i}^{k}$ measures the $k$-th input of country $i$ at time $t$ in logarithms. $X_{i t}=\left(x_{i t}^{1}, x_{i t}^{2}, \ldots, x_{i t}^{K}\right)$ is a vector of all $K$ types of inputs. $f\left(X_{i t}\right)=\alpha+\sum_{k=1}^{K} \beta^{k} x_{i t}^{k}$ describes the production frontier. $u_{i}$ is a non-negative random term that indicates the vertical distance of country $i$ production to the frontier, and hence the gap with the "best practice" level identified by the most productive country. Technical efficiency can be derived by $\mathrm{TE}_{i}=\exp \left(-u_{i}\right)$, which ranges from 0 to $100 \%$. $v_{i}$ is the typical disturbance.

It is worth noting that the technical efficiency term, $u_{i}$, is assumed to be time-invariant in Eq. (1). Therefore, $\alpha_{i}$ can be modeled by the fixed effects or random effects methods. However, the technical efficiency of a country may change over time, as will the debate of convergence and divergence. Moreover, some scholars (e.g., Kumbhakar and Wang (2005), Headey et al. (2010), Inklaar and Diewert (2016), and Zhang et al. (2020)) believe that the Transcendental Logarithmic (T-L) specification for the production function fits data better than the Cobb-Douglas (C-D) specification, as it provides suitable second-order approximations. Accordingly, a stochastic frontier model in T-L specification and time-variant technical efficiency has the form:

$$
y_{i t}=\alpha_{t}+\sum_{k=1}^{K} \beta^{k} x_{i t}^{k}+0.5 \sum_{m=1}^{K} \sum_{n=1}^{K} \beta^{m n} x_{i t}^{n} x_{i t}^{m}-u_{i t}+\nu_{i t},
$$

where $\alpha_{i t}=\alpha_{t}-u_{i t}$ measures total factor productivity in logarithms, which is determined by both the frontier $\alpha_{t}$ and the efficiency $u_{i t}$. Moreover, the productivity growth, $\Delta \alpha_{i t}$, can be decomposed into technological change (shifts in the production frontier, or notionally, $\Delta \alpha_{t}$ ) and efficiency change 
(distance to the frontier, also known as technological catchup, or notionally, $\Delta u_{i t}$ ) (Henderson and Russell 2005).

A new wave of studies (e.g., Cornwell et al. (1990), Kumbhakar (1990), Battese and Coelli (1992), Lee and Schmidt (1993), Kneip et al. (2003), and Sickles (2005)) have developed various models to estimate the time-variant efficiency in the 1990s and 2000s. Shang (2015) and Gong (2020a) introduce a number of competing approaches and compares them under different settings. One of the most popular time-variant estimators is the BC estimator established by Battese and Coelli (1992), where $u_{i t}=\exp (-\eta(t-$ $T)) \cdot u_{i}$ and $u_{i} \sim N^{+}\left(\mu, \sigma_{\mu}^{2}\right)$ is a truncated normal distribution. Under this assumption, Eq. (2) can be solved by Maximum Likelihood Estimation (MLE). Most existing SFA studies, such as Deliktas and Balcilar (2005), Kumbhakar and Wang (2005), and Headey et al. (2010), adopted the BC estimator to investigate economic convergence or technological catch-up.

The $\mathrm{BC}$ estimator has a monotonicity restriction on technical efficiency. Moreover, this monotonic trend has a constant growth rate and is the same for all of the countries, as $\eta$ is time-invariant and country-invariant. If $\eta$ is negative, then technical efficiency is decreasing over time for all countries, therefore leading to a conclusion of economic divergence. The case in which $\eta$ is positive implies that all countries are getting closer to the frontier over time and therefore suggests economic convergences to a single TFP level ( $\sigma$-convergence). A zero $\eta$ indicates that technical efficiency is time invariant, which implies that the gaps across countries do not change over time.

However, the assumption of time-invariant and countryinvariant growth rates in efficiency that is held by the $\mathrm{BC}$ estimator is unrealistic. Aside from the example of the Green Revolution in the previous section, less efficient countries can replicate the production methods, technologies and institutions of efficient and frontier countries. This catch-up effect can be realized through international trade and irrigation investment. International trade makes the new production methods and technologies accessible to less efficient countries, whereas establishing irrigation systems and cultivating new cropland can improve agricultural productivity. Moreover, structural transformation may also affect technical efficiency, since the TFPs for crop production and livestock production are different. Since the efficiency determinants, including international trade, irrigation investment, and structural transformation, change across countries and over time, so does technical efficiency.

This article aims to investigate the efficiency changes in agriculture over the period of 1970-2014, during which both the macro and micro environments changed dramatically. For example, the Green Revolution helped many poor countries produce more food and generated catch-up effects. Some less developed countries, such as China, achieved remarkable agricultural growth as a result of several waves of institutional reforms and market deregulations. The dissolution of the Soviet Union and the establishment of the World Trade Organization (WTO) in the 1990s provided more opportunities for international trade and global cooperation. The $\mathrm{BC}$ estimator fails to capture both the changing macro environment and countrylevel factors due to its rigid assumption of the time-invariant and country-invariant efficiency trend. Therefore, this article employs two other stochastic frontier methods that are more flexible in order to capture the time-variant and country-variant efficiency trend.

The first stochastic frontier model, the CornwellSchmidt-Sickles (CSS) estimator, is proposed by Cornwell et al. (1990), which has a quadratic time-variant intercept of each country based on Eq. (2)

$\alpha_{i t}=\theta_{i 1}+\theta_{i 2} t+\theta_{i 3} t^{2}$

where the quadratic equation of time captures the non-linear trend of efficiency over time, and the country-specific parameters $\theta_{i 1}-\theta_{i 3}$ capture the heterogeneity in the efficiency trend across countries. The CSS model is derived by a Generalized Least Squares (GLS) estimator.

The second stochastic frontier model, the Kneip-SicklesSong (KSS) model, is proposed by Kneip et al. (2012) who believe that country-level efficiencies are affected by some time-variant variables and therefore model efficiencies through a linear combination of some basis functions. Mathematically, the KSS approach models the individual effects in Eq. (2) have the form

$u_{i t}=\sum_{r=1}^{L} \theta_{i r} g_{r}(t)$,

where the basis functions consist of $g_{1}(t), \ldots, g_{L}(t)$, and $\theta_{i 1}, \ldots, \theta_{i L}$ are the corresponding country-specific parameters. As a semi-parametric model, KSS relaxes some rigid formation assumption in the parametric models, such as BC and CSS. Moreover, KSS can be regarded as a generalized model that nests both the BC and CSS estimators. More specifically, if $L=3$ and the polynomial functions are the basis functions, the CSS model is a special case of the KSS model, whereas the BC model is nested in the KSS model if $L=1$ and $g_{1}(t)=\exp (-\eta(t-T)) / \sqrt{\frac{1}{T} \sum_{s=1}^{T} \exp (-\eta(t-T))^{2}}$.

\subsection{A combination of the CSS and KSS models}

There are both advantages and disadvantages to the CSS model and the KSS model. The CSS model is more computationally friendly, but relies heavily on the rigid quadratic formation assumption. The KSS model, however, relaxes the formation assumption to capture a more general 
functional form of the efficiency trend, but may encounter computational challenges. Therefore, the CSS estimator is preferred if the true data generating process (DGP) of efficiency approximates to the quadratic formation; otherwise, it is likely to underperform the KSS estimator. However, the true DGP is unobserved and varies case by case, which makes it necessary to find an optimal approach to better use these estimators.

One popular approach is to use some model selection criterion to choose either CSS or KSS models, such as adjusted $R^{2}$, Akaike Information Criterion (AIC), or Bayesian Information Criterion (BIC). However, a small variation in data might result in different selection of the "best" model under the same criterion if the criterion scores happen to be close across models, not to mention the different results due to varying selection of the criteria. Moreover, more than one candidate model may partially capture the underlying DGP (Shang 2015). In terms of global agricultural production, some countries may have a quadratic trend of productivity growth, whereas other countries may not. The CSS estimator is preferred for the first group of countries and the KSS estimator is preferred for the second group of countries. Finally, the trend of productivity growth for the same countries may also vary over time, and therefore CSS and KSS estimators should be utilized for different periods.

Considering the complexity of the true DGP in crosscountry agricultural production during such a long sample period, we need to find an alternative approach that allows the joint utilization of different candidate models. This article therefore adopts a model averaging method to assign weights to each candidate model based on the model's ability to explain the sample data (Balcombe and Rapsomanikis 2010; Cho and Kasa 2017). If one candidate model dominates in describing the true DGP and approximating the underlying mechanism, model averaging methods can then assign all the weights to that model during model selection. Therefore, model selection is a special case of model averaging. Another advantage of model averaging is the robustness of the estimation results. As has been mentioned, a slight change in data or a different use of criteria may cause a different model selection and very different estimation results. However, such changes have limited effects on the weights assigned to various candidate models and therefore cause limited variation in the estimation results.

Various model averaging methods are applied in the literature. The information criteria-based method assigns weights to candidate models based on information criteria (Buckland et al. 1997; Gong 2018b), such as AIC or BIC. However, the effectiveness and quality improvement are difficult to test. With this concern in mind, a jackknife model averaging (JMA) method, proposed by Hansen and Racine (2012), assigns weights based on a "leave one out" cross-validation criterion. The JMA method is adopted in this article, as it is asymptotically optimal and approaches the minimum expected square errors as the sample size is close to infinity. More specifically, JMA is employed in this article to assign weights to the CSS and KSS models as it best fits the data. Let us denote the jackknife estimates as $\widehat{y}^{\mathrm{CSS}}=\left(\widehat{y}_{1}^{\mathrm{CSS}}, \ldots, \widehat{y}_{n}^{\mathrm{CSS}}\right)$ and $\widehat{y}^{\mathrm{KSS}}=\left(\widehat{y}_{1}^{\mathrm{KSS}}, \ldots, \widehat{y}_{n}^{\mathrm{KSS}}\right)$, where $\widehat{y}_{i}^{\mathrm{CSS}}$ and $\widehat{y}_{i}^{\mathrm{KSS}}$ measure the fitted value of country $i$ 's production utilizing the KSS and CSS methods, respectively, after the observations of the $i$ th country are removed. The jackknife weight $w^{*}$ of CSS model is obtained by minimizing the cross-validation criterion $w^{*}=\operatorname{argmin}_{0 \leq w \leq 1} C V_{n}(w)=\frac{1}{n} \widehat{e}(w)^{\prime} \widehat{e}(w)$, where $\widehat{e}(w)=y-w \widehat{y}^{\mathrm{CSS}}-(1-w) \widehat{y}^{\mathrm{KSS}}$.

As a result, the jackknife model averaging CSS \& KSS stochastic frontier model is

$y_{i t}=w^{*} y_{i t}^{\mathrm{CSS}}+\left(1-w^{*}\right) y_{i t}^{\mathrm{KSS}}$,

where $y_{i t}^{\text {CSS }}$ represents the CSS estimator based on Eqs. (2) and (3), and $y_{i t}^{\text {KSS }}$ represents KSS estimator based on Eqs. (2) and (4). The overall technical efficiency is the jackknifeweighted averages of the CSS and KSS estimators:

$$
\mathrm{TE}_{i t}=\exp \left(-\widehat{u}_{i t}\right)=\exp \left(-\left(w^{*} \widehat{u}_{i t}^{\mathrm{CSS}}+\left(1-w^{*}\right) \widehat{u}_{i t}^{\mathrm{KSS}}\right)\right) .
$$

\subsection{Convergence tests}

To assess the degree of convergence, this article considers three measures. The first method is the $\sigma$-convergence, which measures the cross-sectional dispersion of efficiency changes and has been widely used in existing studies (e.g., Lichtenberg (1994), McCunn and Huffman (2000), and Rezitis (2010)). $\sigma$-convergence implies the extent to which productivity and efficiency levels are becoming more similar over time. To test for $\sigma$-convergence, consider the regression equation

$$
\operatorname{var}(\operatorname{lnTE})_{t}=\phi_{1}+\phi_{2} t+\varepsilon_{t},
$$

where $\operatorname{var}(\operatorname{lnTE})_{t}$ is the variance of technical efficiency for all countries at time $t$ in logarithms, which is computed by $\frac{1}{N} \sum_{i=1}^{N}\left(\ln \left(\mathrm{TE}_{i t}\right)-\ln \overline{\mathrm{TE}}_{t}\right)^{2}$, where $\ln \overline{\mathrm{TE}}_{t}=\frac{1}{N} \sum_{i=1}^{N} \ln \left(\mathrm{TE}_{i t}\right)$ is the average level of efficiency in logarithms. The sufficient condition for $\sigma$-convergence is that $\phi_{2}$ is significantly negative, which implies the convergence to the frontier for all countries over time. Otherwise, the unconditional $\sigma$-convergence does not happen. Furthermore, when the test rejects unconditional $\sigma$-convergence, it can then be employed to subgroups of countries (e.g., McCunn and Huffman (2000)) or to sub-periods (e.g., Rezitis (2010)), 
which extends a test of convergence across all countries within a group or during a subperiod.

The second method is the unconditional $\beta$-convergence, which occurs when less efficient countries grow faster than more efficient ones. Following Sala-i-Martin (1996) and Young et al. (2008), an unconditional $\beta$-convergence equation is proposed of the form in this article

$\Delta \mathrm{TE}_{i t}=\phi_{1}+\phi_{2} \mathrm{TE}_{i, t-1}+\varepsilon_{t}$,

where $\mathrm{TE}_{i, t-1}$ is the technical efficiency in the previous period and $\Delta \mathrm{TE}_{i t}=100 *\left(\mathrm{TE}_{\mathrm{it}}-\mathrm{TE}_{i, t-1}\right)$ measures the percentage change in efficiency for country $i$ at time $t$. When $\phi_{2}$ is statistically significant negative, it implies that less efficient countries grow faster.

The third method is the conditional $\beta$-convergence, which implies possible channels through which convergence can be achieved or accelerated in the future. A conditional $\beta$-convergence occurs when countries experience $\beta$-convergence that is conditional on other variables (i.e., the state of each country). This article establishes a conditional $\beta$-convergence equation of the form

$$
\Delta \mathrm{TE}_{i t}=\phi_{1}+\phi_{2} \mathrm{TE}_{i, t-1}+\gamma Z_{i, t-1}+\varepsilon_{t},
$$

where $Z$ is a vector of variables that may affect agricultural technical efficiency, which includes the total volume of international trade (trade), proportion of cropland to total agricultural land (cropland), proportion of agricultural land that is irrigated (irrig), and the output ratio of livestock in total products (livestock). A conditional $\beta$-convergence is accepted if $\phi_{2}$ in Eq. (9) is negative and significantly different from zero. Some scholars (e.g., Raiser (1998) and McCunn and Huffman (2000)) replace previous period efficiency $\operatorname{lnTE} E_{i, t-1}$ with $\operatorname{lnTE} E_{i, t 0}$ in the $\beta$-convergence equation to measure the initial level of efficiency and therefore define less efficient and more efficient countries. This revision may not work well for studying agricultural convergence, as it relies heavily on the first year of the sample period. Agricultural production suffers from great risk and uncertainty, which leads to frequent fluctuation in productivity and efficiency, especially for small and poor countries. As a result, a different selection of the initial period may cause very different results. Since the dependent variable $\Delta \mathrm{TE}_{i t}$ is in the range $0-100$, this article uses a Tobit model to solve Eqs. (7) and (8). Moreover, this article follows Kumbhakar et al. (2015) to correct the standard errors using the bootstrap method.

This article uses the aforementioned measures ( $\sigma$-convergence, unconditional $\beta$-convergence, and conditional $\beta$ convergence) to test agricultural convergence for 126 countries during the period from 1970-2014. Moreover, this article tests the $\sigma$-convergence and $\beta$-convergence for various groups that may share the same steady state, in addition to the test of the whole world: (1) Since geographic condition is time invariant and highly related to the initial conditions of the countries, this article tests agricultural convergence in different regions. ${ }^{2}$ (2) Bartkowska and Riedl (2012) point out that the initial condition of per capita income plays a crucial role in determining convergence groups. This article also tests the convergence for low-income, lower middle-income, upper middle-income, and high-income countries, as countries in each of the four groups are likely to have a similar initial level of per capita income. (3) Another popular classification of countries is less developed countries (LDCs) and developed countries (DCs), which not only reflects the difference in income level, but also many other development factors that may lead countries to different steady states. Therefore, the third set of convergence tests is for DCs and LDCs separately. (4) International trade enhances the speed of technology transfer (Cameron et al. 2005) and therefore affects convergence. As a result, it may be easier to achieve convergence in GATT/WTO member countries. This article therefore tests agricultural catch-up for GATT/WTO member countries and non-member countries. (5) An alternative classification of developing countries that not only considers development level, but focuses on agricultural development level, is proposed in the World Development Report 2008: Agriculture for Development by World Bank (World Bank, 2007), which indicates that agriculture operates in three different worlds: agriculture-based, transforming and urbanized countries $^{3}$. This article also tests if convergence occurs within each of these three groups in addition to developed countries.

\subsection{Endogeneity problem}

The stochastic frontier model may experience an endogeneity problem because some productivity information considered in the decision-making process of production is unobservable by scholars (Ackerberg et al. 2015; Gong and Sickles 2021). Amsler et al. (2016) introduce a way to solve endogeneity in stochatic frontier models. Following their approach, this article tests the endogeneity of each input by employing a control function method and correct the bias if

\footnotetext{
2 The eight geographic regions are developed Africa, Sub-Saharan Africa, North America, Latin America, Europe, Asia, WANA (West Asia and North Africa), and Oceania. Agricultural convergence within the same regions might be easier due to the convenience of population and resource flow, such as in EU (Pasquali, 2020).

${ }^{3}$ The contributions of agriculture differ in these three groups. All developing countries are divided into these three groups based on the share of agriculture in aggregate GDP growth over the last 15 years, and the current ratio of total poverty in rural areas based on a poverty line of \$2-a-day. Agriculture-based countries are mainly Sub-Saharan nations, where agriculture is a major source of growth. Transforming countries are mainly in East Asia and MENA, where the contribution of agriculture to GDP growth is small but poverty mainly occur in rural areas. Urbanized countries are those in Central Asia and Europe as well as Latin America and the Caribbean, where agriculture contributes even less to GDP growth, and the share of poverty in rural areas is smaller. To summarize, agriculture-based countries are least developed whereas urbanized countries are relatively developed.
} 
necessary. Lagged values of inputs are employed to serve as instruments, which is recommended in Levinsohn and Petrin (2003), Guan et al. (2009), and Gong (2018a).

An endogeneity problem may also occur in the conditional $\beta$-convergence function in Eq. (9), since international trade may affect technical efficiency and thus lead to a reverse causation issue. The instrument variable (IV) method is usually employed to solve this bias. This article uses per capita agricultural production $\left(a g r i \_p c_{i t}\right)$ and per capita arable land (land_p $c_{i t}$ ) as instruments for international trade, which is suggested in Chanda and Dalgaard (2008) and Madsen (2009). Moreover, the delayed value of international trade can also mitigate the causality problem.

\section{Data}

Following Gong (2020b), country-level agricultural input and output data for 1970-2014 are collected from the Economic Research Service of the United States Department of Agriculture (USDA-ERS). ${ }^{4}$ Output is measured by the sum of the production value of 189 crop and livestock $\operatorname{commodities}\left(Y_{i t}\right.$, in billions of international dollars at 2005 's constant price), which is initially reported in the FAO. USDA-ERS also reports six agricultural inputs, including agricultural labor $\left(\right.$ labor $_{i t}$, in millions of economically active adults), agricultural land ( $\operatorname{land}_{i t}$, in millions of hectares of rain-fed cropland equivalents), livestock capital on farms (livestock $k_{i}$, in thousands of cattle equivalents), total animal feed ( feed $_{i}$, in millions of metric tons of crops and crop processing residues calculated in dry-matter equivalents), fertilizer consumption (fertilizer ${ }_{i t}$, in millions of metric tons of $\mathrm{N}, \mathrm{P} 2 \mathrm{O} 5, \mathrm{~K} 2 \mathrm{O}$ ), and total stock of farm machinery (machinery ${ }_{i t}$, in millions of $40-\mathrm{CV}$ tractor equivalents). These variables are used in CSS and KSS models to estimate technical efficiency with the help of the JMA method.

Moreover, USDA-ERS also reports the proportion of cropland to total agricultural land $\left(\right.$ cropland $\left._{i t}\right)$ as well as the proportion of agricultural land that is irrigated $\left(\right.$ irrig $\left._{i t}\right)$ and separates countries into eight geographical regions and four income classes as mentioned in Section 2.3. Data for the total volume of international trade in agricultural products $\left(\right.$ trade $\left._{i t}\right)$ are collected from the NBER-UN database for 1970-1994 and the CEPII-BACI database for 1995-2014..$^{5}$ The output share of livestock in total agricultural products (livestock ${ }_{i t}$ ) is collected and calculated from FAO's

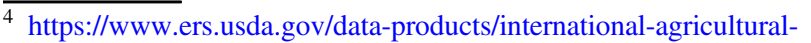
productivity/

5 Detailed introduction of NBER-UN database and CEPII-BACI database can be found in Gong (2020b).
}

database. The list of GATT/WTO members is available on the WTO website, ${ }^{6}$ whereas the list of developed countries is from the International Monetary Fund (IMF). Population size $\left(\right.$ pop $\left._{i t}\right)$ is collected from World Bank databases. Finally, per capita arable land $\left(l a n d \_p c_{i t}\right)$ and per capita agricultural production $\left(a g r i \_p c_{i t}\right)$ are calculated using population data from World Bank databases and agricultural output and land data from USDA-ERS.

Combining all the data mentioned above, this article is based on a balanced panel of 126 countries from 1970-2014. These countries account for roughly $86 \%$ of the world's total population and $82 \%$ of the world's total agricultural production in 1970, whereas these two figures increased to 89 and $90 \%$, respectively, by 2014 . Table 1 presents the distribution of these countries under various classifications in 2014. Under geographic classification, countries in America, Europe and Oceania have abundant agricultural products as their shares of agricultural products are higher than their shares of population, whereas low per capita agricultural output and shortages of food mainly occurred in Sub-Saharan African countries as they account for $11.2 \%$ of global population, but only produce $5.5 \%$ of the world's agricultural output. In terms of income levels, low-income and lower middle-income countries, on average, have per capita agricultural outputs that are significantly and slightly lower than the world average, respectively, whereas high-income and upper middleincome countries on average have per capita agricultural outputs that are significantly and slightly higher than world average, respectively. Therefore, income level also seems like a valid standard to classify countries into different groups that may have different conditions in agriculture. The same conclusion applies to development groups, trade groups and agricultural groups, as various groups under each of the three classifications have a significantly different per capita agricultural output. More specifically, developed countries, GATT/WTO members, and urbanized countries on average have better agricultural conditions than less developed countries, non-GATT/WTO members, and agriculture-based countries, respectively. In summary, significant differences in agriculture across groups are observed under all five classifications. Therefore, convergence tests are also applied within each group under these classifications.

Table 2 provides summary statistics of the key variables. These 126 countries on average generated agricultural products worth 10.3 billion international dollars at 2005's constant price. Roughly $60 \%$ of the agricultural outputs are

\footnotetext{
${ }^{6}$ Information about GATT members and WTO members are separately available at https://www.wto.org/english/thewto_e/gattmem_e. htm and https://www.wto.org/english/thewto_e/whatis_e/tif_e/org6_e. htm.
} 
Table 1 Classification and distribution of countries in 2014

\begin{tabular}{|c|c|c|c|c|c|}
\hline \multirow[t]{2}{*}{ Classifications } & \multirow[t]{2}{*}{$\begin{array}{l}\# \text { of } \\
\text { nations }\end{array}$} & \multirow[t]{2}{*}{$\begin{array}{l}\% \text { of world } \\
\text { population }\end{array}$} & \multirow{2}{*}{$\begin{array}{l}\% \text { of } \\
\text { world } \\
\text { agri- } \\
\text { output }\end{array}$} & \multicolumn{2}{|c|}{$\begin{array}{l}\text { Agricultural } \\
\text { output }\end{array}$} \\
\hline & & & & Mean & Median \\
\hline All Countries & 126 & $89.1 \%$ & $90.4 \%$ & 18.3 & 3.7 \\
\hline \multicolumn{6}{|c|}{ Geographical Regions } \\
\hline $\begin{array}{l}\text { Sub-Saharan } \\
\text { Africa }\end{array}$ & 34 & $11.2 \%$ & $5.5 \%$ & 4.2 & 2.2 \\
\hline Asia & 22 & $51.4 \%$ & $44.9 \%$ & 52.3 & 8.3 \\
\hline $\begin{array}{l}\text { WANA (N. Africa } \\
\& \text { W. Asia) }\end{array}$ & 17 & $6.3 \%$ & $5.1 \%$ & 7.7 & 3.2 \\
\hline $\begin{array}{l}\text { South \& Central } \\
\text { America }\end{array}$ & 25 & $8.5 \%$ & $12.7 \%$ & 13.0 & 3.3 \\
\hline Europe & 23 & $5.7 \%$ & $9.1 \%$ & 10.1 & 5.1 \\
\hline Developed Africa & 1 & $0.7 \%$ & $0.6 \%$ & 14.1 & 14.1 \\
\hline North America & 2 & $4.9 \%$ & $11.0 \%$ & 140.6 & 140.6 \\
\hline Oceania & 2 & $0.4 \%$ & $1.5 \%$ & 19.4 & 19.4 \\
\hline \multicolumn{6}{|l|}{ Income Groups } \\
\hline Low-income & 25 & $7.7 \%$ & $3.3 \%$ & 3.3 & 2.8 \\
\hline $\begin{array}{l}\text { Lower Middle- } \\
\text { income }\end{array}$ & 28 & $34.8 \%$ & $23.0 \%$ & 21.0 & 5.0 \\
\hline $\begin{array}{l}\text { Upper Middle- } \\
\text { income }\end{array}$ & 32 & $31.5 \%$ & $36.9 \%$ & 31.5 & 3.7 \\
\hline High-income & 41 & $15.5 \%$ & $24.8 \%$ & 15.5 & 4.7 \\
\hline \multicolumn{6}{|l|}{ Development Groups } \\
\hline Less Developed & 100 & $76.6 \%$ & $69.1 \%$ & 17.8 & 3.4 \\
\hline Developed & 26 & $12.5 \%$ & $21.0 \%$ & 20.7 & 7.2 \\
\hline \multicolumn{6}{|l|}{ Trade Groups } \\
\hline $\begin{array}{l}\text { Non-GATT/WTO } \\
\text { Members }\end{array}$ & 15 & $5.0 \%$ & $2.7 \%$ & 4.6 & 1.8 \\
\hline $\begin{array}{l}\text { GATT/WTO } \\
\text { Members }\end{array}$ & 111 & $84.1 \%$ & $87.7 \%$ & 20.2 & 4.1 \\
\hline \multicolumn{6}{|l|}{ Agricultural Groups } \\
\hline Agriculture-based & 36 & $10.7 \%$ & $6.1 \%$ & 4.3 & 2.8 \\
\hline Transforming & 38 & $54.9 \%$ & $47.0 \%$ & 31.6 & 3.7 \\
\hline Urbanized & 26 & $11.0 \%$ & $16.0 \%$ & 16.3 & 4.1 \\
\hline
\end{tabular}

The last two columns give mean and median value of agricultural output in billion international dollars at 2005 constant price, respectively

crops and $40 \%$ are livestock-related products. In terms of agricultural inputs, these countries on average use a 7.0 million-strong labor force, 15.1 thousand cattle equivalents of livestock capital, 0.2 million tractor equivalents of farm machinery, 0.8 million metric tons of fertilizer, and 6.7 million metric tons of feed, in addition to utilizing 13.3 million hectares of agricultural land, where $79 \%$ is cropland and $12 \%$ is equipped for irrigation. Moreover, the average volume of international trade is 5.9 billion dollars. Finally, the average per capita amount of arable land is 0.44 hectare, and the average per capita agricultural products are valued at 310 international dollars at 2005 's constant price.

\section{Estimation results}

\subsection{Frontier and efficiency estimates}

Table 3 reports the estimation results of various SFA models. The first and second columns show the results of the CSS and KSS models, respectively. The jackknife weight assigned to the CSS model is 0.489 , whereas the weight assigned to the KSS model is 0.511 , which shows that both models can partially capture the true DGP, but the semi-parametric KSS weighs more. Column 3 of Table 3 reports the estimation result of the model averaging CSS \& KSS stochastic frontier model using the jackknife weights reported in the first two columns. Based on Column 3, labor elasticity and livestock elasticity are the greatest, followed by the elasticity of land and feed, whereas the elasticity of machinery and fertilizer are the lowest.

Using the estimations in Table 3, this article calculates the output elasticity with respect to each input across models: (1) 0.262 (labor), 0.173 (land), 0.133 (livestock capital), 0.088 (machinery capital), 0.175 (fertilizers), 0.136 (animal feed) in CSS model; (2) 0.243 (labor), 0.193 (land), 0.143 (livestock capital), 0.099 (machinery capital), 0.168 (fertilizers), 0.131 (animal feed) in KSS model; and (3) 0.252 (labor), 0.183 (land), 0.138 (livestock capital), 0.094 (machinery capital), 0.171 (fertilizers), 0.133 (animal feed) in model averaging CSS \& KSS model. Therefore, output elasticities are robust in various models. Moreover, during the sample period, the factor shares of labor, land, livestock capital, machinery capital, fertilizers, and animal feed reported in USDA-ERS are $0.317,0.208,0.131,0.091$, 0.135 , and 0.120 , respectively, which are consistent with our estimations. ${ }^{7}$

Table 4 presents country-level technical efficiency estimated by the CSS, KSS, and jackknife averaging CSS \& KSS models. The average efficiency level of agricultural production is $35 \%$, which implies great potential to increase agricultural output. Even without technical progress, the global agricultural output can almost triple if all countries can achieve the highest attainable productivity on the frontier through efficiency improvement, which could significantly contribute to sustainable development and poverty reduction. Moreover, the distribution of technical efficiency is right skewed as more than three-quarters of the countries are less than half as efficient as the frontier countries. One-quarter of these 126 countries have an efficiency level of less than $21 \%$; these are the least developed countries with severe hunger and poverty. All of these facts provide evidence of the great importance of agricultural convergence if technological catch-up occurred in those

\footnotetext{
7 https://www.ers.usda.gov/data-products/international-agriculturalproductivity/
} 
Table 2 Summary statistics

\begin{tabular}{lllcccc}
\hline Variable Name & Notation & Unit & Mean & St. Dev. & Min & Max \\
\hline Agricultural output & $Y$ & Billion international \$ & 11.2 & 37.4 & 0.0 & 590 \\
Agricultural land & land & Million hectares & 13.6 & 40.9 & 0.0 & 316 \\
Agricultural labor & labor & Million active adults & 7.3 & 34.3 & 0.0 & 391 \\
Livestock capital & livestock & Thousand cattle equivalents & 15.8 & 45.2 & 0.0 & 415 \\
Farm machinery & machine & Million tractor equivalents & 0.2 & 0.7 & 0.0 & 12.0 \\
Fertilizer consumption & fertilizer & Million metric tons & 0.9 & 3.6 & 0.0 & 51 \\
Animal feed & feed & Million metric tons & 7.3 & 24.6 & 0.0 & 370 \\
Agricultural trade & trade & Billion dollars & 6.9 & 18.0 & 0.0 & 273 \\
Share of cropland & cropland & \% & 79 & 19 & 0 & 100 \\
Share of irrigated land & irrig & \% & 12 & 13 & 0 & 71 \\
Share of livestock & livestock & \% & 40 & 23 & 0 & 99 \\
Per capita arable land & land_pc & Hectare & 0.41 & 0.61 & 0.00 & 6.70 \\
Per capita agri output & agri_pc & Thousand international \$ & 0.31 & 0.29 & 0.00 & 2.67 \\
\hline
\end{tabular}

least efficient countries. Otherwise, the world will face more challenges between the growing population and food scarcity if agricultural divergence is observed.

Table 5 reports the change of technical efficiency between 1970 and 2014 for various groups. To summarize, different groups in different classifications reflect different efficiency trends for the period from 1970-2014. Significant efficiency decrease is witnessed in lagging groups, such as low-income, less developed, agriculture-based, and African countries, whereas efficiency increase is observed in more advanced groups, such as high-income, developed, urbanized and European countries. Overall, the gap between advanced and lagging groups is enlarged during the last five decades.

\subsection{Tests for $\sigma$-convergence}

Table 6 reports the estimation results of $\sigma$-convergence tests for all countries and for various groups of countries. It is worth noting that each row presents the results for one regression where variance in efficiency is the dependent variable and time trend is the independent variable. This article finds no evidence of world agricultural convergence using a $\sigma$-convergence test. In contrast, the first row in Table 6 implies larger efficiency dispersion over time, which indicates agricultural divergence.

The results of $\sigma$-convergence in Table 6 show that agricultural convergence occurred within lagging regions, such as low-income, less developed, agriculture-based, and African countries, respectively. This implies that the countries are getting closer to group-specific frontier countries. A possible explanation of these findings is that technology sharing and access are only available within the same group and are limited from the advanced countries.

On the contrary, the advanced groups, such as developed countries, and urbanized countries, experienced divergence during the same period, indicating larger gaps across countries within the same group. In other words, some countries are more efficient, whereas others are less efficient. This may be less problematic, for example, for urbanized countries since agriculture may account for a relatively small portion of their GDP. Food insecurity and mass poverty won't happen as long as their productivity and efficiency in nonagricultural sectors are high and the international trade of agricultural products remains unobstructed.

\subsection{Tests for unconditional $\beta$-convergence}

Table 7 presents the estimation results of the unconditional $\beta$-convergence tests under various classifications, which links the efficiency growth to the efficiency level of the countries that were ignored in the $\sigma$-convergence tests. For all 126 of the countries, the unconditional $\beta$-convergence test also rejects world agricultural convergence. Moreover, this article finds unconditional $\beta$-divergence, which implies that more efficient countries grow faster than less efficient countries.

The results of unconditional $\beta$-convergence tests under different classifications are fairly consistent with the findings in $\sigma$-convergence tests. Advanced economies, such as developed countries and urbanized countries, experienced agricultural divergence. Agricultural convergence, on the other hand, is witnessed among lagging economies, such as Sub-Saharan African countries, low-income countries, less developed countries, and agriculture-based countries, which indicates that less efficient nations grow faster within each of these groups.

\subsection{Tests for conditional $\beta$-convergence}

The final question this article aims to answer is whether all countries can converge to a single point in the future? 
Table 3 Estimation results of the stochastic frontier models

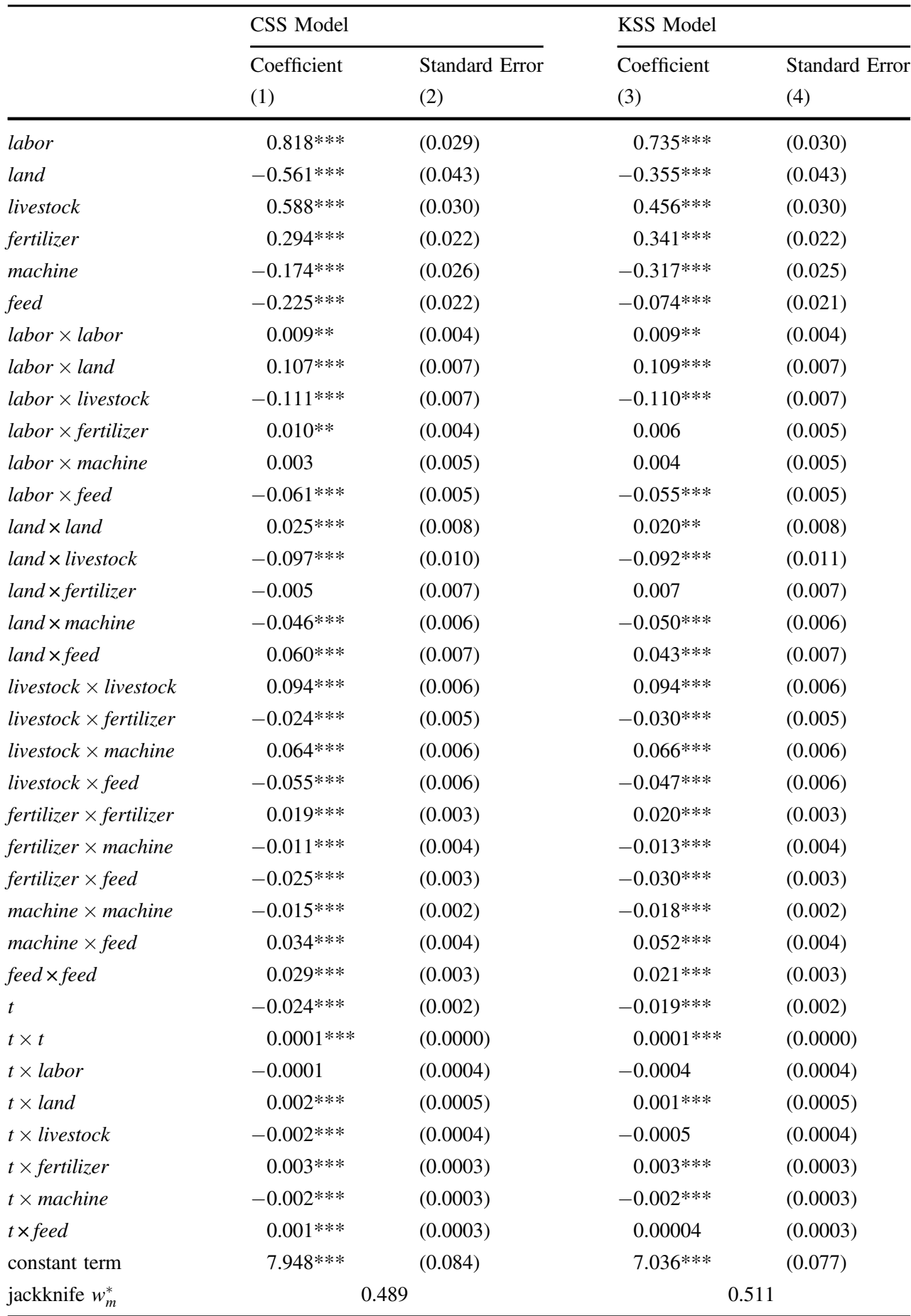

Standard errors are given in parentheses

Asterisks *,**, and $* * *$ denote significance at the $1 \%, 5 \%$, and $10 \%$ levels, respectively
Tables 8 and 9 report the estimation results of the conditional $\beta$-convergence tests. When other variables are held constant, $\beta$-convergence is witnessed for world agricultural production, indicating that it is possible to achieve global convergence. Moreover, among all the 16 groups under different classifications, 11 groups achieved conditional within-group convergence, 2 groups suffered from conditional within-group divergence, and the remaining 2 groups experienced neither convergence nor divergence.

This article is also interested in the role of other growth drivers on convergence. By comparing the coefficients of lagged efficiency in the unconditional convergence analysis (Table 7) with the ones in the conditional convergence analysis (Tables 8 and 9), we can test if considering these 
Table 4 Technical efficiency statistics

CSS Model KSS Model Jackknife Average Model

(1)

\begin{tabular}{llll}
\hline Mean & 0.37 & 0.34 & 0.35 \\
Minimum & 0.10 & 0.09 & 0.10 \\
$25 \%$ quantile & 0.22 & 0.20 & 0.21 \\
$50 \%$ quantile & 0.31 & 0.28 & 0.29 \\
$75 \%$ quantile & 0.48 & 0.44 & 0.46 \\
Maximum & 1.00 & 1.00 & 1.00 \\
\hline
\end{tabular}

Table 5 Technical efficiency and its changes by group

\begin{tabular}{|c|c|c|c|}
\hline Classifications & 1970 & 2014 & Change \\
\hline All Countries & 0.381 & 0.355 & -0.026 \\
\hline \multicolumn{4}{|l|}{ Geographical Regions } \\
\hline Sub-Saharan Africa & 0.352 & 0.244 & -0.108 \\
\hline South \& Central America & 0.347 & 0.339 & -0.008 \\
\hline Asia & 0.288 & 0.289 & 0.001 \\
\hline WANA (W. Asia \& N. Africa) & 0.396 & 0.428 & 0.032 \\
\hline Europe & 0.516 & 0.513 & -0.003 \\
\hline \multicolumn{4}{|l|}{ Income Groups } \\
\hline Low-income & 0.313 & 0.213 & -0.100 \\
\hline Lower Middle-income & 0.282 & 0.271 & -0.011 \\
\hline Upper Middle-income & 0.344 & 0.363 & 0.019 \\
\hline High-income & 0.518 & 0.501 & -0.017 \\
\hline \multicolumn{4}{|l|}{ Development Groups } \\
\hline Less Developed & 0.349 & 0.309 & -0.040 \\
\hline Developed & 0.537 & 0.554 & 0.017 \\
\hline \multicolumn{4}{|l|}{ Trade Groups } \\
\hline Non-GATT/WTO Members & 0.327 & 0.308 & -0.019 \\
\hline GATT/WTO Members & 0.423 & 0.362 & -0.061 \\
\hline \multicolumn{4}{|l|}{ Agricultural Groups } \\
\hline Agriculture-based & 0.334 & 0.247 & -0.087 \\
\hline Transforming & 0.318 & 0.325 & 0.007 \\
\hline Urbanized & 0.369 & 0.379 & 0.010 \\
\hline
\end{tabular}

growth drivers have contributed to world agricultural convergence. In full sample analysis, the coefficient changed from positive in the unconditional test to negative in the conditional test, indicating openness to trade and other factors controlled contributed to world agricultural convergence. Among all the 16 comparisons at group level, $75 \%(12 / 16)$ of the results indicate that openness to trade and other factors contributed to within-group convergence.

The results of the conditional $\beta$-convergence tests also indicate how to improve efficiency and accelerate convergence in different countries in the future. Overall, the total volume of international trade, share of cropland in total agricultural land, and share of irrigated land have significantly positive, although different, effects on agricultural efficiency in most groups. More specifically, international trade is more important and has a greater impact on efficiency improvement in the lagging countries, whereas the effect is smaller in the leading countries. In terms of cropland ratio, transforming, high-income, WANA and GATT/WTO countries can benefit more from cropland than other countries. Irrigation construction can also significantly improve technical efficiency in most countries. Livestock production is more efficient than crop production in the leading countries (e.g., Europe, urbanized, highincome, and developed countries) but crop production is more efficient in the lagging countries (e.g., Sub-Saharan Africa and lower middle-income countries), as the coefficient of livestock $k_{t-1}$ is significantly positive in the former groups but significantly negative in the latter groups.

\subsection{Robustness checks}

The first concern is the reliability of technical efficiency calculations. We check the robustness of the current Trans$\log$ SFA model by introducing two more models. On the one hand, this article introduces technical efficiency calculated by the DEA method to see if the consistent convergence results hold, which can relax fixed functional forms in the SFA method. Some scholars (e.g., Kumar and Russell (2002), Coelli and Rao (2005), and Henderson and Russell (2005)) estimate efficiency using the DEA method in agricultural convergence studies, which implements a nonparametric representation of the frontier. This article follows Deliktas and Balcilar (2005) and Headey et al. (2010) by using the DEA as a confirmatory analysis to supplement the results in the SFA. In the DEA model, the efficiency is predicted by solving the following linear programming equation:

$D_{i t}\left(y_{i t}, x_{i t}\right)=\min _{\theta, \lambda} \theta$

s.t. $-y_{i t}+Y \lambda \geq 0, \theta x_{i t}+X \lambda \geq 0, \lambda \geq 0$,

where $Y$ accounts for the output matrix of $y_{i t}$, and $X$ accounts for the input matrix of $x_{i t}$. $\lambda$ vectors a group of constants. The efficiency score is measured by $\theta$, which is comparable to the one derived from the SFA models. On the other hand, the true DGP remains unobserved, making it difficult for a single method to explain the agricultural technical efficiency trend sufficiently for all countries. Taking the complexity of the true DGP in cross-country agricultural production into account, this article therefore adopts the Jackknife averaging modeling procedure as the benchmark, which can assign weights based on the ability of each candidate model to explain the sample data We also 
Table 6 Estimation results of $\sigma$ convergence tests

\begin{tabular}{|c|c|c|c|c|c|}
\hline \multirow[t]{2}{*}{ Classifications } & \multicolumn{2}{|l|}{ Time Trend } & \multicolumn{2}{|l|}{ Intercept } & \multirow[t]{2}{*}{ Conclusion } \\
\hline & coefficient & SE & coefficient & SE & \\
\hline All Countries & $0.0014 * * *$ & $(0.000)$ & $-2.332 * * *$ & $(0.385)$ & Divergence \\
\hline \multicolumn{6}{|l|}{ Geographical Regions } \\
\hline Sub-Saharan Africa & $-0.0014 * * *$ & $(0.000)$ & $3.043 * * *$ & $(0.223)$ & Convergence \\
\hline South \& Central America & $0.0012 * * *$ & $(0.000)$ & $-2.366^{* * *}$ & $(0.254)$ & Divergence \\
\hline Asia & $0.0005 * * *$ & $(0.000)$ & $-0.843^{* * *}$ & $(0.243)$ & Divergence \\
\hline WANA (W. Asia \& N. Africa) & $-0.0029 * * *$ & $(0.000)$ & $6.114 * * *$ & $(0.408)$ & Convergence \\
\hline Europe & -0.00004 & $(0.000)$ & 0.260 & $(0.243)$ & Neither \\
\hline \multicolumn{6}{|l|}{ Income Groups } \\
\hline Low-income & $-0.0021 * * *$ & $(0.000)$ & $4.438 * * *$ & $(0.009)$ & Convergence \\
\hline Lower Middle-income & $0.0014 * * *$ & $(0.000)$ & $-2.635 * * *$ & $(0.220)$ & Divergence \\
\hline Upper Middle-income & $-0.0005^{* * *}$ & $(0.000)$ & $1.220 * * *$ & $(0.290)$ & Convergence \\
\hline High-income & -0.0001 & $(0.000)$ & 0.413 & $(0.490)$ & Neither \\
\hline \multicolumn{6}{|l|}{ Development Groups } \\
\hline Less Developed & $-0.0001^{*}$ & $(0.000)$ & $-0.010 * *$ & $(0.119)$ & Convergence \\
\hline Developed & $0.0002 * *$ & $(0.000)$ & -0.274 & $(0.208)$ & Divergence \\
\hline \multicolumn{6}{|l|}{ Trade Groups } \\
\hline Non-GATT/WTO Members & $0.0016^{* * *}$ & $(0.000)$ & $-2.847 * * *$ & $(0.378)$ & Divergence \\
\hline GATT/WTO Members & $0.0007 * * *$ & $(0.000)$ & $-1.181 * * *$ & $(0.216)$ & Divergence \\
\hline \multicolumn{6}{|l|}{ Agricultural Groups } \\
\hline Agriculture-based & $-0.0015^{* * *}$ & $(0.000)$ & $3.184 * * *$ & $(0.236)$ & Convergence \\
\hline Transforming & $0.0010 * * *$ & $(0.000)$ & $-1.662 * * *$ & $(0.178)$ & Divergence \\
\hline Urbanized & $0.0013 * * *$ & $(0.000)$ & $-2.552 * * *$ & $(0.257)$ & Divergence \\
\hline
\end{tabular}

Standard errors are given in parentheses

Asterisks *,**, and $* * *$ denote significance at the $1 \%, 5 \%$, and $10 \%$ levels, respectively employ the CSS and KSS technical efficiency scores to test the robustness of the baseline estimates.

Table 10 compares the convergence results using technical efficiency scores calculated by different models. The first four columns in Table 2 present the results of $\sigma$ convergence tests with the TE scores of different models. For all countries, all the three additional convergence tests deliver consistent results with our main model using SFA technical efficiency scores. In the heterogeneity analysis, the proportion of the three robust convergence results that are consistent with the main model is more than $85 \%$. Columns (5)-(8) show the results of the unconditional $\beta$ convergence tests. For all countries, the convergence results based on TE scores of CSS, KSS and DEA methods deliver consistent conclusion that unconditional $\beta$-convergence has not occurred for all countries. Among the seventeen comparisons, the proportions of results from additional analysis that are consistent with the main model is over $75 \%$. Columns (9)-(12) show that conditional $\beta$-convergence in agricultural technical efficiency is witnessed in all countries with different TE scores calculation methods. Among the seventeen comparisons, more than $90 \%$ of them show the same result. As a result, the additional analysis confirms the robustness of our baseline estimates.

The second concern is the quality of the USDA-ERS datasets. Although there are some defects in the USDAERS data, it may still be difficult to replace (Villoria 2019). The main reasons are as follows: first, although developed countries such as the United States and Australia have better databases, there is a lack of comparable data for developing countries. Second, the statistical standards of different countries are varied, which may produce additional errors in the merge of data. In order to address the possible problems posed by using the USDA-ERS data, we conduct a robustness check on the main regression results using the agricultural value-added data for each country from 1970-2018 provided by United Nations $(\mathrm{UN})^{8}$, which has been widely used in studies related to agriculture productivity, such as Gollin et al. (2014). This article establishes a value-added production function for world

\footnotetext{
${ }^{8}$ UN data do not include complete data for Democratic Republic of Congo and Ethiopia. Therefore, we use a panel data for 124 countries from 1970-2014 to estimate technical efficiency and test convergence.
} 
Table 7 Estimation results of unconditional $\beta$ -

convergence tests

\begin{tabular}{|c|c|c|c|c|c|}
\hline \multirow[t]{2}{*}{ Classifications } & \multicolumn{2}{|c|}{ Lagged Efficiency } & \multicolumn{2}{|l|}{ Intercept } & \multirow[t]{2}{*}{ Conclusion } \\
\hline & coefficient & SE & coefficient & SE & \\
\hline All Countries & $0.033 * * *$ & $(0.004)$ & $-0.034 * * *$ & $(0.016)$ & Divergence \\
\hline \multicolumn{6}{|l|}{ Geographical Regions } \\
\hline Sub-Saharan Africa & $-2.497 * * *$ & $(0.081)$ & $0.357 * * *$ & $(0.025)$ & Convergence \\
\hline South \& Central America & $1.187 * * *$ & $(0.164)$ & $-0.378 * * *$ & $(0.052)$ & Divergence \\
\hline Asia & $0.209 *$ & $(0.120)$ & -0.009 & $(0.033)$ & Divergence \\
\hline WANA (W. Asia \& N. Africa) & $0.272 * * *$ & $(0.089)$ & $0.084 * *$ & $(0.040)$ & Divergence \\
\hline Europe & $0.371 * * *$ & $(0.083)$ & $-0.144 * *$ & $(0.045)$ & Divergence \\
\hline \multicolumn{6}{|l|}{ Income Groups } \\
\hline Low-income & $-2.169 * * *$ & $(0.074)$ & $0.272 * * *$ & $(0.021)$ & Convergence \\
\hline Lower Middle-income & 0.207 & $(0.202)$ & $-0.064 * *$ & $(0.031)$ & Neither \\
\hline Upper Middle-income & -0.096 & $(0.108)$ & 0.045 & $(0.039)$ & Neither \\
\hline High-income & $0.287 * * *$ & $(0.082)$ & -0.050 & $(0.043)$ & Divergence \\
\hline \multicolumn{6}{|l|}{ Development Groups } \\
\hline Less Developed & $-0.309 * * *$ & $(0.054)$ & 0.029 & $(0.018)$ & Convergence \\
\hline Developed & $0.253 * * *$ & $(0.087)$ & $-0.084 *$ & $(0.049)$ & Divergence \\
\hline \multicolumn{6}{|l|}{ Trade Groups } \\
\hline Non-GATT/WTO Members & $-0.929 * * *$ & $(0.102)$ & $0.120 * * *$ & $(0.033)$ & Convergence \\
\hline GATT/WTO Members & $0.113 * * *$ & $(0.044)$ & $-0.047 * * *$ & $(0.018)$ & Divergence \\
\hline \multicolumn{6}{|l|}{ Agricultural Groups } \\
\hline Agriculture-based & $-2.713 * * *$ & $(0.090)$ & $0.452 * * *$ & $(0.028)$ & Convergence \\
\hline Transforming & 0.076 & $(0.076)$ & 0.006 & $(0.026)$ & Neither \\
\hline Urbanized & $0.885 * * *$ & $(0.109)$ & $-0.271 * * *$ & $(0.040)$ & Divergence \\
\hline
\end{tabular}

Standard errors are given in parentheses

Asterisks *,**, and $* * *$ denote significance at the $1 \%, 5 \%$, and $10 \%$ levels, respectively agricultural sector in the form:

Value added $_{i t}=\alpha_{t}+\sum_{k=1}^{K} \beta^{k} x_{i t}^{k}+0.5 \sum_{m=1}^{K} \sum_{n=1}^{K} \beta^{m n} x_{i t}^{n} x_{i t}^{m}-u_{i t}+\nu_{i t}$

where Valuedded $_{i t}$ accounts for the agricultural value-added of country $i$ at time $t$ in logarithms, and $x_{i}^{k}$ measures the $k$-th input of country $i$ at time $t$ in logarithms. Compared to the input choice in Eq. (2), we don't include the intermediate input variables, such as animal feed and fertilizer, as suggested in literature.

Thirdly, the technical efficiency in agriculture from yearto-year data may be violated in responding to some transitory shocks. Following Barro and Sala-I-Martin (1991) and Wang et al. (2019), this article uses the average rate of technical efficiency growth (TFP growth rate in their model) over the interval $\mathrm{T}$ ( 3 years and 5 years, respectively) to calculate $\sigma$-convergence test, unconditional $\beta$-convergence test and conditional $\beta$-convergence test.

Table 11 compares the convergence results between the year-to-year analysis and the period-to-period analysis using the USDA-ERS data, as well as the ones using the UN data. The first four columns in Table 11 present the results of $\sigma$-convergence tests. For all the countries, the $\sigma$-convergence tests' results in our main model are consistent with those considering 3-year average and those using the UN value-added data ${ }^{9}$. Columns (5)-(8) show the results of the unconditional $\beta$-convergence tests. For all countries, the results of the unconditional $\beta$-convergence tests considering 3 -year lag or using the value-added data are consistent with our main model. The unconditional $\beta$-convergence tests with 5-year lag are inconsistent with our main model because of the small sample size. Among the seventeen comparisons, the proportion of results that are consistent with the data set corresponding to the main model is nearly $75 \%$. Columns (9)-(12) show that the conditional $\beta$-convergence in agricultural technical efficiency is witnessed in all countries with different data settings. Among the seventeen comparisons, more than $90 \%$ of them show the same result, which confirms the robustness of our baseline results.

\footnotetext{
${ }_{9}$ Many estimates using 5-year average data are insignificant due to small sample size, which leads to the conclusion of neither convergence nor divergence and the notation " $N$ " in Table 11.
} 


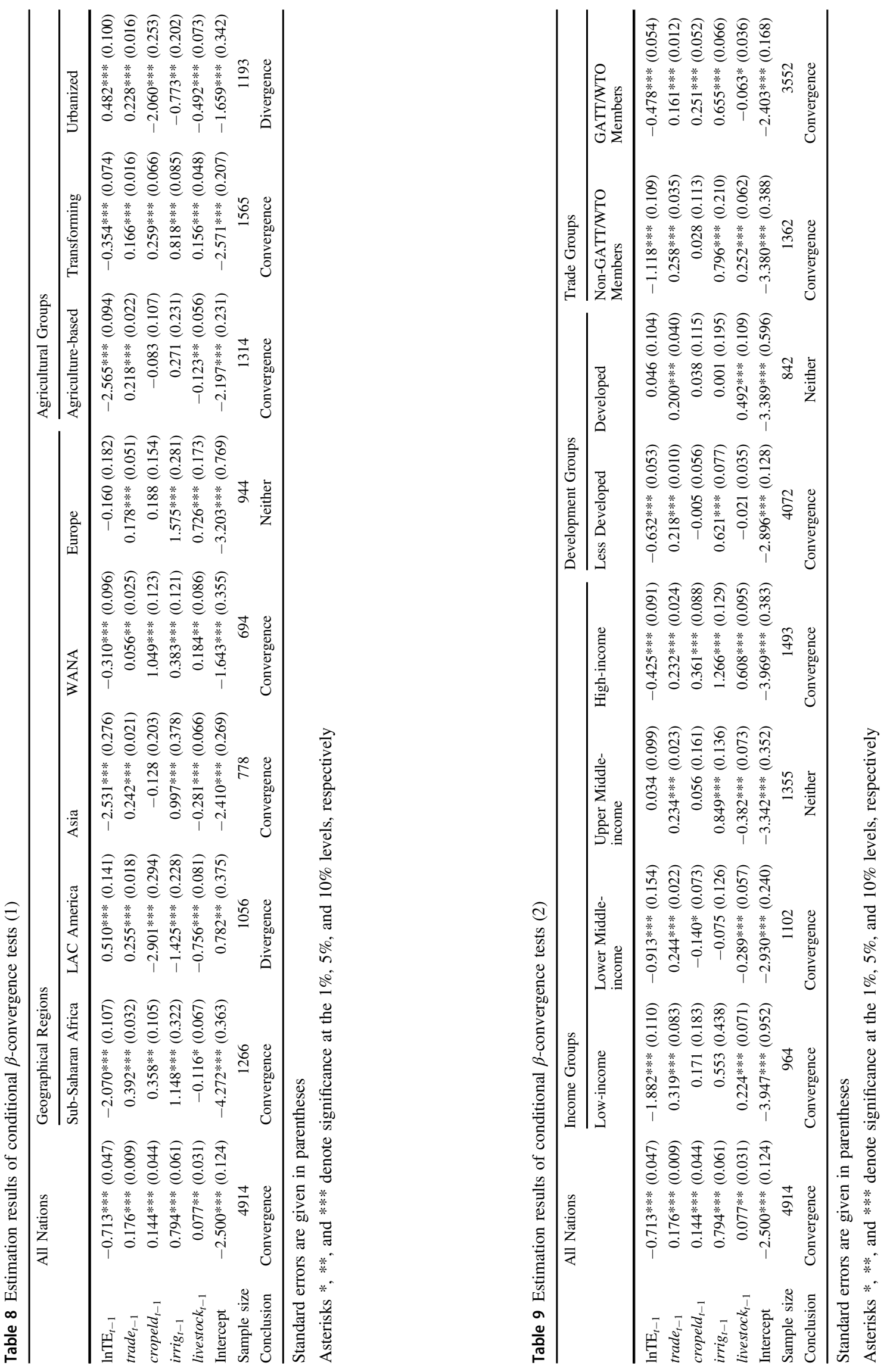


Table 10 Robustness checks for various efficiency models

\begin{tabular}{|c|c|c|c|c|c|c|c|c|c|c|c|c|}
\hline \multirow[t]{2}{*}{ Classifications } & \multicolumn{4}{|c|}{$\sigma$-convergence tests } & \multicolumn{4}{|c|}{$\begin{array}{l}\text { Unconditional } \\
\beta \text {-convergence tests }\end{array}$} & \multicolumn{4}{|c|}{$\begin{array}{l}\text { Conditional } \\
\beta \text {-convergence tests }\end{array}$} \\
\hline & Main & CSS & KSS & DEA & Main & CSS & KSS & DEA & Main & CSS & KSS & DEA \\
\hline All Countries & $\mathrm{D}$ & $\mathrm{D}$ & $\mathrm{D}$ & $\mathrm{D}$ & $\mathrm{D}$ & $\underline{N}$ & $\mathrm{D}$ & $\mathrm{D}$ & $\mathrm{C}$ & $\mathrm{C}$ & $\mathrm{C}$ & $\mathrm{C}$ \\
\hline \multicolumn{13}{|c|}{ Geographical Regions } \\
\hline $\begin{array}{l}\text { Sub-Saharan } \\
\text { Africa }\end{array}$ & $\mathrm{C}$ & $\mathrm{C}$ & $\mathrm{C}$ & $\mathrm{C}$ & $\mathrm{C}$ & $\mathrm{C}$ & $\mathrm{C}$ & $\mathrm{C}$ & $\mathrm{C}$ & $\mathrm{C}$ & $\mathrm{C}$ & $\mathrm{C}$ \\
\hline LAC America & $\mathrm{D}$ & $\mathrm{D}$ & $\mathrm{D}$ & C & $\mathrm{D}$ & $\mathrm{D}$ & $\mathrm{D}$ & $\mathrm{D}$ & $\mathrm{D}$ & $\mathrm{D}$ & $\underline{N}$ & $\underline{\mathrm{C}}$ \\
\hline Asia & $\mathrm{D}$ & $\mathrm{D}$ & $\mathrm{D}$ & $\underline{N}$ & $\mathrm{D}$ & $\underline{N}$ & $\underline{N}$ & $\underline{N}$ & $\mathrm{C}$ & $\mathrm{C}$ & $\mathrm{C}$ & $\mathrm{C}$ \\
\hline WANA & $\mathrm{C}$ & $\mathrm{C}$ & $\mathrm{C}$ & $\mathrm{C}$ & $\mathrm{D}$ & $\mathrm{D}$ & $\mathrm{D}$ & $\underline{N}$ & $\mathrm{C}$ & $\mathrm{C}$ & $\underline{\mathrm{D}}$ & $\mathrm{C}$ \\
\hline Europe & $\mathrm{N}$ & $\mathrm{N}$ & $\mathrm{N}$ & $\mathrm{N}$ & $\mathrm{D}$ & $\mathrm{D}$ & $\mathrm{D}$ & $\mathrm{D}$ & $\mathrm{N}$ & $\mathrm{N}$ & $\mathrm{N}$ & $\underline{\mathrm{C}}$ \\
\hline \multicolumn{13}{|l|}{ Income Groups } \\
\hline Low-income & $\mathrm{C}$ & $\mathrm{C}$ & $\mathrm{C}$ & $\mathrm{C}$ & $\mathrm{C}$ & $\mathrm{C}$ & $\mathrm{C}$ & $\mathrm{C}$ & $\mathrm{C}$ & $\mathrm{C}$ & $\mathrm{C}$ & $\mathrm{C}$ \\
\hline $\begin{array}{l}\text { Lower Middle- } \\
\text { income }\end{array}$ & $\mathrm{D}$ & $\mathrm{D}$ & $\mathrm{D}$ & $\mathrm{D}$ & $\mathrm{N}$ & $\underline{\mathrm{D}}$ & $\mathrm{N}$ & $\mathrm{N}$ & $\mathrm{C}$ & $\mathrm{C}$ & $\mathrm{C}$ & $\mathrm{C}$ \\
\hline $\begin{array}{l}\text { Upper Middle- } \\
\text { income }\end{array}$ & $\mathrm{C}$ & $\mathrm{C}$ & $\mathrm{C}$ & $\mathrm{C}$ & $\mathrm{N}$ & $\mathrm{N}$ & $\mathrm{N}$ & $\mathrm{N}$ & $\mathrm{N}$ & $\mathrm{N}$ & $\mathrm{N}$ & $\underline{\mathrm{C}}$ \\
\hline High-income & $\mathrm{N}$ & $\mathrm{N}$ & $\mathrm{N}$ & $\mathrm{N}$ & $\mathrm{D}$ & $\mathrm{D}$ & $\underline{N}$ & $\mathrm{D}$ & $\mathrm{C}$ & $\mathrm{C}$ & $\mathrm{C}$ & $\mathrm{C}$ \\
\hline \multicolumn{13}{|c|}{ Development Groups } \\
\hline Less Developed & $\mathrm{C}$ & $\underline{N}$ & $\mathrm{C}$ & $\mathrm{C}$ & $\mathrm{C}$ & $\mathrm{C}$ & $\mathrm{C}$ & $\mathrm{C}$ & $\mathrm{C}$ & $\mathrm{C}$ & $\mathrm{C}$ & $\mathrm{C}$ \\
\hline Developed & $\mathrm{D}$ & $\underline{N}$ & $\mathrm{D}$ & $\underline{N}$ & $\mathrm{D}$ & $\mathrm{D}$ & $\underline{N}$ & $\underline{N}$ & $\mathrm{~N}$ & $\mathrm{~N}$ & $\mathrm{~N}$ & $\mathrm{~N}$ \\
\hline \multicolumn{13}{|l|}{ Trade Groups } \\
\hline $\begin{array}{l}\text { Non-GATT/ } \\
\text { WTO Members }\end{array}$ & $\mathrm{D}$ & $\mathrm{D}$ & $\mathrm{D}$ & $\mathrm{D}$ & $\mathrm{C}$ & $\mathrm{C}$ & $\mathrm{C}$ & $\mathrm{C}$ & $\mathrm{C}$ & $\mathrm{C}$ & $\mathrm{C}$ & $\mathrm{C}$ \\
\hline $\begin{array}{l}\text { GATT/WTO } \\
\text { Members }\end{array}$ & $\mathrm{D}$ & $\mathrm{D}$ & $\mathrm{D}$ & $\mathrm{D}$ & $\mathrm{D}$ & $\mathrm{D}$ & $\underline{N}$ & $\underline{\mathrm{C}}$ & $\mathrm{C}$ & $\mathrm{C}$ & $\mathrm{C}$ & $\mathrm{C}$ \\
\hline \multicolumn{13}{|c|}{ Agricultural Groups } \\
\hline $\begin{array}{l}\text { Agriculture- } \\
\text { based }\end{array}$ & $\mathrm{C}$ & $\mathrm{C}$ & $\mathrm{C}$ & $\mathrm{C}$ & $\mathrm{C}$ & $\mathrm{C}$ & $\mathrm{C}$ & $\mathrm{C}$ & $\mathrm{C}$ & $\mathrm{C}$ & $\mathrm{C}$ & $\mathrm{C}$ \\
\hline Transforming & $\mathrm{D}$ & $\mathrm{D}$ & $\mathrm{D}$ & $\underline{\mathrm{C}}$ & $\mathrm{N}$ & $\mathrm{N}$ & $\mathrm{N}$ & $\underline{\mathrm{C}}$ & $\mathrm{C}$ & $\mathrm{C}$ & $\mathrm{C}$ & $\mathrm{C}$ \\
\hline Urbanized & $\mathrm{D}$ & $\mathrm{D}$ & $\mathrm{D}$ & $\mathrm{D}$ & $\mathrm{D}$ & $\mathrm{D}$ & $\mathrm{D}$ & $\mathrm{D}$ & $\mathrm{D}$ & $\mathrm{D}$ & $\mathrm{D}$ & $\mathrm{D}$ \\
\hline $\begin{array}{l}\text { \# of Consistent } \\
\text { Results }\end{array}$ & - & $15 / 17$ & $17 / 17$ & $13 / 17$ & - & $14 / 17$ & $13 / 17$ & $12 / 17$ & - & $17 / 17$ & $15 / 17$ & $14 / 17$ \\
\hline
\end{tabular}

$\mathrm{D}$ represents divergence, $\mathrm{C}$ represents convergence, and $\mathrm{N}$ represents neither of the two. The underscored results are inconsistent with the ones of the main model. The last row presents consistent results of the corresponding model with the main model among the seventeen comparisons

\subsection{Discussion and Policy Implication}

On the one hand, convergence is achieved for lagging country groups, such as Sub-Saharan African countries, low-income countries, less developed countries, and agriculture-based countries, in all $\sigma$-convergence and $\beta$ convergence tests. This indicates that the gap within each group is decreasing and seems to be a good signal of catchup. However, these lagging country groups all witnessed a significant decrease in average efficiency in Table 5, which implies that they are even further behind advanced countries now than they were in 1970. Taking both findings into consideration, the leaders in these lagging country groups are less efficient, which diminishes the within-group gap, but extends the cross-group gap. To summarize, the once most-promising countries in the lagging groups fail to catch up and the gap between lagging countries and advanced countries is enlarged. On the other hand, advanced country groups, such as developed countries, raised average efficiency and therefore converged. However, $\sigma$-divergence and unconditional $\beta$-divergence are also observed in these groups. These findings together imply that more countries are catching up to the frontier, whereas the rest of them are falling behind in these advanced groups. To empirically verify this hypothesis, we reference the method used by Jin et al. (2010) to measure technological progress of the two groups (developed countries and developing countries). The results show that the average annual growth rates of 
Table 11 Robustness checks for various data settings

\begin{tabular}{|c|c|c|c|c|c|c|c|c|c|c|c|c|}
\hline \multirow[t]{2}{*}{ Classifications } & \multicolumn{4}{|c|}{$\sigma$-convergence tests } & \multicolumn{4}{|c|}{ Unconditional $\beta$-convergence tests } & \multicolumn{4}{|c|}{ Conditional $\beta$-convergence tests } \\
\hline & Main & $\begin{array}{l}3 \text {-year } \\
\text { average }\end{array}$ & $\begin{array}{l}5 \text {-year } \\
\text { average }\end{array}$ & $\begin{array}{l}\text { UN } \\
\text { Data }\end{array}$ & Main & $\begin{array}{l}3 \text {-year } \\
\text { average }\end{array}$ & $\begin{array}{l}5 \text {-year } \\
\text { average }\end{array}$ & $\begin{array}{l}\text { UN } \\
\text { Data }\end{array}$ & Main & $\begin{array}{l}3 \text {-year } \\
\text { average }\end{array}$ & $\begin{array}{l}5 \text {-year } \\
\text { average }\end{array}$ & $\begin{array}{l}\text { UN } \\
\text { Data }\end{array}$ \\
\hline All Countries & $\mathrm{D}$ & $\mathrm{D}$ & $\mathrm{D}$ & $\mathrm{D}$ & $\mathrm{D}$ & $\mathrm{D}$ & $\underline{N}$ & $\mathrm{D}$ & $\mathrm{C}$ & $\mathrm{C}$ & $\mathrm{C}$ & $\mathrm{C}$ \\
\hline \multicolumn{13}{|l|}{ Geographical Regions } \\
\hline Sub-Saharan Africa & $\mathrm{C}$ & $\underline{\mathrm{N}}$ & $\underline{N}$ & $\mathrm{C}$ & $\mathrm{C}$ & $\mathrm{C}$ & $\mathrm{C}$ & $\mathrm{C}$ & $\mathrm{C}$ & $\mathrm{C}$ & $\mathrm{C}$ & $\mathrm{C}$ \\
\hline LAC America & $\mathrm{D}$ & $\mathrm{D}$ & $\mathrm{D}$ & $\mathrm{D}$ & $\mathrm{D}$ & $\mathrm{D}$ & $\underline{N}$ & $\mathrm{D}$ & $\mathrm{D}$ & $\underline{N}$ & $\underline{N}$ & $\mathrm{D}$ \\
\hline Asia & $\mathrm{D}$ & $\underline{N}$ & $\underline{\mathrm{N}}$ & $\mathrm{D}$ & $\mathrm{D}$ & $\mathrm{D}$ & $\mathrm{D}$ & $\underline{N}$ & $\mathrm{C}$ & $\mathrm{C}$ & $\mathrm{C}$ & $\mathrm{C}$ \\
\hline WANA & $\mathrm{C}$ & $\mathrm{C}$ & $\underline{\mathrm{N}}$ & $\underline{N}$ & $\mathrm{D}$ & $\mathrm{D}$ & $\mathrm{D}$ & $\mathrm{D}$ & $\mathrm{C}$ & $\mathrm{C}$ & $\mathrm{C}$ & $\mathrm{C}$ \\
\hline Europe & $\mathrm{N}$ & $\mathrm{N}$ & $\mathrm{N}$ & $\mathrm{N}$ & $\mathrm{D}$ & $\mathrm{D}$ & $\mathrm{D}$ & $\mathrm{D}$ & $\mathrm{N}$ & $\mathrm{N}$ & $\mathrm{N}$ & $\mathrm{N}$ \\
\hline \multicolumn{13}{|l|}{ Income Groups } \\
\hline Low-income & $\mathrm{C}$ & $\mathrm{C}$ & $\mathrm{C}$ & $\mathrm{C}$ & $\mathrm{C}$ & $\mathrm{C}$ & $\mathrm{C}$ & $\mathrm{C}$ & $\mathrm{C}$ & $\mathrm{C}$ & $\mathrm{C}$ & $\mathrm{C}$ \\
\hline $\begin{array}{l}\text { Lower Middle- } \\
\text { income }\end{array}$ & $\mathrm{D}$ & $\mathrm{D}$ & $\underline{\mathrm{N}}$ & $\mathrm{D}$ & $\mathrm{N}$ & $\mathrm{N}$ & $\mathrm{N}$ & $\mathrm{N}$ & $\mathrm{C}$ & $\mathrm{C}$ & $\mathrm{C}$ & $\mathrm{C}$ \\
\hline $\begin{array}{l}\text { Upper Middle- } \\
\text { income }\end{array}$ & $\mathrm{C}$ & $\mathrm{C}$ & $\mathrm{C}$ & $\mathrm{C}$ & $\mathrm{N}$ & $\mathrm{N}$ & $\mathrm{N}$ & $\mathrm{N}$ & $\mathrm{N}$ & $\underline{\mathrm{C}}$ & $\underline{\mathrm{C}}$ & $\mathrm{N}$ \\
\hline High-income & $\mathrm{N}$ & $\mathrm{N}$ & $\mathrm{N}$ & $\mathrm{N}$ & $\mathrm{D}$ & $\underline{N}$ & $\underline{N}$ & $\underline{N}$ & $\mathrm{C}$ & $\mathrm{C}$ & $\mathrm{C}$ & $\mathrm{C}$ \\
\hline \multicolumn{13}{|l|}{ Development Groups } \\
\hline Less Developed & $\mathrm{C}$ & $\underline{N}$ & $\underline{N}$ & $\underline{N}$ & $\mathrm{C}$ & $\mathrm{C}$ & $\mathrm{C}$ & $\mathrm{C}$ & $\mathrm{C}$ & $\mathrm{C}$ & $\mathrm{C}$ & $\mathrm{C}$ \\
\hline Developed & $\mathrm{D}$ & $\underline{N}$ & $\mathrm{D}$ & $\mathrm{D}$ & $\mathrm{D}$ & $\underline{N}$ & $\mathrm{D}$ & $\mathrm{D}$ & $\mathrm{N}$ & $\mathrm{N}$ & $\mathrm{N}$ & $\mathrm{N}$ \\
\hline \multicolumn{13}{|l|}{ Trade Groups } \\
\hline $\begin{array}{l}\text { Non-GATT/WTO } \\
\text { Members }\end{array}$ & $\mathrm{D}$ & $\mathrm{D}$ & $\underline{N}$ & $\mathrm{D}$ & $\mathrm{C}$ & $\mathrm{C}$ & $\mathrm{C}$ & $\mathrm{C}$ & $\mathrm{C}$ & $\mathrm{C}$ & $\mathrm{C}$ & $\mathrm{C}$ \\
\hline $\begin{array}{l}\text { GATT/WTO } \\
\text { Members }\end{array}$ & $\mathrm{D}$ & $\mathrm{D}$ & $\underline{N}$ & $\mathrm{D}$ & $\mathrm{D}$ & $\mathrm{D}$ & $\underline{N}$ & $\mathrm{D}$ & $\mathrm{C}$ & $\mathrm{C}$ & $\mathrm{C}$ & $\mathrm{C}$ \\
\hline \multicolumn{13}{|l|}{ Agricultural Groups } \\
\hline Agriculture-based & $\mathrm{C}$ & $\mathrm{C}$ & $\underline{N}$ & $\mathrm{C}$ & $\mathrm{C}$ & $\mathrm{C}$ & $\mathrm{C}$ & $\mathrm{C}$ & $\mathrm{C}$ & $\mathrm{C}$ & $\mathrm{C}$ & $\mathrm{C}$ \\
\hline Transforming & $\mathrm{D}$ & $\underline{N}$ & $\underline{N}$ & $\mathrm{D}$ & $\mathrm{N}$ & $\underline{\mathrm{C}}$ & $\underline{\mathrm{C}}$ & $\underline{D}$ & $\mathrm{C}$ & $\mathrm{C}$ & $\mathrm{C}$ & $\underline{N}$ \\
\hline Urbanized & $\mathrm{D}$ & $\mathrm{D}$ & $\mathrm{D}$ & $\mathrm{D}$ & $\mathrm{D}$ & $\mathrm{D}$ & $\mathrm{D}$ & $\mathrm{D}$ & $\mathrm{D}$ & $\mathrm{D}$ & $\mathrm{D}$ & $\mathrm{D}$ \\
\hline $\begin{array}{l}\text { \# of Consistent } \\
\text { Results }\end{array}$ & - & $12 / 17$ & $8 / 17$ & $15 / 17$ & - & $14 / 17$ & $12 / 17$ & $14 / 17$ & - & $15 / 17$ & $15 / 17$ & $16 / 17$ \\
\hline
\end{tabular}

$\mathrm{D}$ represents divergence, $\mathrm{C}$ represents convergence, and $\mathrm{N}$ represents neither of the two. The underscored results are inconsistent with the ones of the main model. The last row presents consistent results of the corresponding data settings with the main model among the seventeen comparisons

technological progress are 1.268 and $1.136 \%$ for developed countries and less developed countries, respectively, which supports these aforementioned conclusions.

Another interesting finding is that many groups achieve convergence only after other variables are controlled in the conditional $\beta$-convergence test, which implies that the agricultural efficiency gap can diminish in the ideal state when all other things are equal. Therefore, agricultural catch-up can be obtained if the lagging countries can improve irrigation system, international trade, and optimize crop-livestock structure based on relative advantages. This is of great significance to sustainable development and poverty reduction on a global scale. However, countries with lower agricultural efficiency may not be able to improve their level of relevant efficiency determinants by themselves and will therefore fail to diminish the efficiency gap. Hence, support from other countries and related organizations are necessary to achieve convergence.

Finally, we find that the "within-group" efficiency divergence in rich countries is mainly due to the faster technological process, whereas the "within-group" efficiency convergence in poor countries is the result of slow growth in its frontier country. Therefore, technology transfers and spillovers from rich countries to poor countries are very important to accelerate the growth in the frontier of the poor countries.

\section{Conclusion}

The aim of this article is to answer two questions: Has world agricultural convergence occurred? If not, how can 
this goal be fulfilled? Existing studies find that the SFA method is better than the DEA method in studying world agricultural catch-up, since it can capture the random noise and measurement error. However, the classic SFA estimator cannot capture the non-monotonic trend of technical efficiency. This article uses both CSS and KSS models to estimate more accurate country-level technical efficiency in agriculture. Three convergence tests are then employed to answer the two aforementioned questions. To our knowledge, this is the first study that employs the model averaging method to investigate world agricultural convergence. Compared with existing studies, this article also analyzes regional agricultural convergence and the potential approaches to improve agricultural efficiency and accelerate technological catch-up in different countries.

Using a balanced panel of 126 countries for the period from 1970-2014, this article finds that the global average technical efficiency is 0.35 , indicating the potential to increase agricultural output and the importance of agricultural convergence. Unconditional measures of convergence show all countries fail to converge to a single point. Moreover, it is possible for all countries to converge to the same equilibrium based on the conditional convergence test. This article finds that international trade and irrigation system can help diminish the efficiency gap and achieve agricultural catch-up in lagging countries.

This article further investigates a within-group single steady state is achieved for different groups of countries. Lagging countries groups, such as Sub-Sahara African countries, low-income countries, less developed countries and agriculture-based countries, achieved $\sigma$-convergence and unconditional $\beta$-convergence, which implies that the within-group gaps are diminishing over time. However, the convergence is due to the slow development of the leaders in these lagging groups, rather than the catch-up of the laggards, since their gaps and distances toward the advanced countries are enlarged. Moreover, the laggards in the advanced country groups also witnessed decreasing efficiency and therefore led to divergence within those advanced groups. To summarize, the middling countries suffered from stagnation, which is the major obstacle to world agricultural convergence.

Moreover, we find that even after controlling country differences in international trade, irrigation system and structural transformation, a puzzlingly large gap remains among advanced groups such as European countries, and developed countries. Future studies can investigate how to diminish this gap and how to solve the stagnation issue of the middling countries. Moreover, this article uses widely accepted classifications to do cluster convergence analysis, such as by geographical location, income level, development level, openness levels, and agricultural importance, respectively. How to identify more rational agriculture- based classification using other methods, such as club convergence tests, is worth investigating in the future. Finally, existing studies find negative impact of epidemics on agricultural productivity (Gong et al. 2020), it is necessary to evaluate the short-run and long-run effects of COVID-19 on world agricultural convergence when relevant data are available.

Acknowledgements We acknowledge the financial support of the National Natural Science Foundation of China (71903172), Soft Science Research Program of the Ministry of Agriculture and Rural Affairs (RKX202001A), Project of Leading Talents of Social Sciences in Zhejiang Province (21QNYC05ZD), Soft Science Research Program of Zhejiang Province (2020C25020), Qianjiang Talent Program (QJC1902008), and ZJU-IFPRI Center for International Development Studies at Zhejiang University.

\section{Compliance with ethical standards}

Conflict of interest The authors declare no competing interests.

Publisher's note Springer Nature remains neutral with regard to jurisdictional claims in published maps and institutional affiliations.

\section{References}

Ackerberg DA, Caves K, Frazer G (2015) Identification properties of recent production function estimators. Econometrica 83:2411-2451

Aigner D, Lovell CA, Schmidt P (1977) Formulation and estimation of stochastic frontier production function models. J Econ 6:21-37

Alene AD, Coulibaly O (2009) The impact of agricultural research on productivity and poverty in sub-Saharan Africa. Food Policy 34:198-209

Alston JM, Pardey PG (2014) Agriculture in the Global Economy. J Econ Perspect 28:121-146

Amsler C, Prokhorov A, Schmidt P (2016) Endogeneity in stochastic frontier models. J Econ 190:280-288

Ashraf Q, Galor O (2011) Dynamics and stagnation in the Malthusian epoch. Am Econ Rev 101:2003-2041

Balcombe K, Rapsomanikis G (2010) An analysis of the impact of research and development on productivity using Bayesian model averaging with a reversible jump algorithm. Am J Agri Econ 92:985-998

Barro RJ, Sala-I-Martin X (1991) Convergence across States and Regions. Brook Papers Econ Activity 1991:107-182

Bartkowska M, Riedl A (2012) Regional convergence clubs in Europe: Identification and conditioning factors. Econ Modell 29:22-31

Battese GE, Coelli TJ (1992) Frontier production functions, technical efficiency and panel data: With application to paddy farmers in India. Springer, Netherlands

Buckland ST, Burnham KP, Augustin NH (1997) Model selection: an integral part of inference. Biometrics 53:603-618

Bustos P, Caprettini B, Ponticelli J (2016) Agricultural productivity and structural transformation: Evidence from Brazil. Am Econ Rev 106:1320-1365

Cameron G, Proudman J, Redding S (2005) Technological convergence, $\mathrm{R} \& \mathrm{D}$, trade and productivity growth. Eur Econ Rev 49:775-807

Carillo MF (2018) Agricultural policy and long-run development: evidence from Mussolini's Battle for Grain. University Library of Munich, Germany 
Chanda A, Dalgaard CJ (2008) Dual economies and international total factor productivity differences: channelling the impact from institutions, trade, and geography. Economica 75:629-661

Chen S, Gong B (2021) Response and adaptation of agriculture to climate change: evidence from China. J Dev Econ 148:102557

Cho I-K, Kasa K (2017) Gresham's Law of Model Averaging. Am Econ Rev 107:3589-3616

Coelli T, Rungasuriyawiboon S, Rao D (2004) Sensitivity of the Malmquist Productivity Index to the Choice of Methodology: An Application to World Agriculture. Mimeograph, Centre for Efficiency and Productivity Analysis, School of Economics, The University of Queensland, Brisbane, Australia

Coelli TJ, Rao D (2005) Total factor productivity growth in agriculture: a Malmquist index analysis of 93 countries, 1980-2000. Agric Econ 32:115-134

Cornwell C, Schmidt P, Sickles RC (1990) Production frontiers with cross-sectional and time-series variation in efficiency levels. J Econ 46:185-200

Deliktas E, Balcilar M (2005) A comparative analysis of productivity growth, catch-up, and convergence in transition economies. Emerg Markets Finance Trade 41:6-28

Lee YH, Schmidt P. (1993) A production frontier model with flexible temporal variation in technical efficiency. The measurement of productive efficiency: Techniques and applications, $237-255$

Foster AD, Rosenzweig MR (1996) Technical change and humancapital returns and investments: evidence from the green revolution. Am Econ Rev 86:931-953

Foster AD, Rosenzweig MR (2004) Agricultural productivity growth, rural economic diversity, and economic reforms: India, 1970-2000. Econ Dev Cultural Change 52:509-542

Galor O, Mountford A (2008) Trading population for productivity: theory and evidence. Rev Econ Stud 75:1143-1179

Gollin D, Lagakos D, Waugh ME (2014) The agricultural productivity gap. Quarterly J Econ 129:939-993

Gong B (2018a) Agricultural reforms and production in China changes in provincial production function and productivity in 1978-2015. J Dev Econ 132:18-31

Gong B (2018b) Interstate competition in agriculture: Cheer or fear? Evidence from the United States and China. Food Policy $81: 37-47$

Gong B (2020a) Agricultural productivity convergence in China. China Econ Rev 60:101423

Gong B (2020b) New Growth Accounting. Am J Agric Econ 102:641-661

Gong B, Sickles RC (2020) Non-structural and structural models in productivity analysis: study of the British Isles during the 2007-2009 financial crisis. J Product Anal 53:243-263

Gong B, Zhang S, Yuan L, Chen KZ (2020) A balance act: minimizing economic loss while controlling novel coronavirus pneumonia. J Chinese Governance 5:249-268

Gong B, Zhang S, Liu X, Chen KZ (2021) The zoonotic diseases, agricultural production, and impact channels: evidence from China. Global Food Security 28:100463

Gong B, Sickles RC (2021) Resource allocation in multi-divisional multi-product firms. J Product Anal Forthcom.

Greene W (2005) Reconsidering heterogeneity in panel data estimators of the stochastic frontier model. J Econ 126:269-303

Greene WH (2008) The econometric approach to efficiency analysis. The measurement of productive efficiency and productivity growth 1:92-250

Guan Z, Kumbhakar SC, Myers RJ, Lansink AO (2009) Measuring excess capital capacity in agricultural production. Am J Agric Econ 91:765-776

Hansen BE, Racine JS (2012) Jackknife model averaging. J Econ $167: 38-46$
Headey D, Alauddin M, Rao D (2010) Explaining agricultural productivity growth: an international perspective. Agric Econ 41:1-14

Henderson DJ, Russell RR (2005) Human capital and convergence: a production-frontier approach. Int Econ Rev 46:1167-1205

Inklaar R, Diewert WE (2016) Measuring industry productivity and cross-country convergence. J Econ 191:426-433

Jin S, Deininger K (2009) Land rental markets in the process of rural structural transformation: productivity and equity impacts from China. J Comp Econ 37:629-646

Jin S, Huang J, Hu R, Rozelle S (2002) The creation and spread of technology and total factor productivity in China's agriculture. Am J Agric Econ 84:916-930

Jin S, Ma H, Huang J, Hu R, Rozelle S (2010) Productivity, efficiency and technical change: measuring the performance of China's transforming agriculture. J Product Anal 33:191-207

Kneip A, Sickles R, Song W (2003) On estimating a mixed effects model with applications to the U.S. banking industry. Rice University, Mimeo

Kneip A, Sickles RC, Song W (2012) A new panel data treatment for heterogeneity in time trends. Econ Theory 28:590-628

Kögel T, Prskawetz A (2001) Agricultural productivity growth and escape from the Malthusian trap. J Econ Growth 6:337-357

Kumar S, Russell RR (2002) Technological change, technological catch-up, and capital deepening: relative contributions to growth and convergence. Am Econ Rev 92:527-548

Kumbhakar SC (1990) Production frontiers, panel data, and timevarying technical inefficiency. J Econ 46:201-211

Kumbhakar SC, Wang H-J (2005) Estimation of growth convergence using a stochastic production frontier approach. Econ Lett 88:300-305

Kumbhakar SC, Lien G, Hardaker JB (2014) Technical efficiency in competing panel data models: a study of Norwegian grain farming. J Product Anal 41:321-337

Kumbhakar SC, Wang, H-J, Horncastle, AP (2015) A practitioner's guide to stochastic frontier analysis using Stata. Cambridge: Cambridge University Press

Levinsohn J, Petrin A (2003) Estimating production functions using inputs to control for unobservables. Rev Econ Stud 70:317-341

Lewis WA (1954) Economic development with unlimited supplies of labour. Manch School 22:139-191

Lichtenberg FR (1994) Testing the convergence hypothesis. Rev Econ Stat 76:576-579

Ma W, Bicknell K, Renwick A (2019) Feed use intensification and technical efficiency of dairy farms in New Zealand. Aust J Agric Resour Econ 63:20-38

Madsen JB (2007) Technology spillover through trade and TFP convergence: 135 years of evidence for the OECD countries. J Int Econ 72:464-480

Madsen JB (2009) Trade barriers, openness, and economic growth. South Econ J 76:397-418

Matsuyama K (1992) Agricultural productivity, comparative advantage, and economic growth. J Econ Theory 58:317-334

McCunn A, Huffman WE (2000) Convergence in US productivity growth for agriculture: implications of interstate research spillovers for funding agricultural research. Am J Agric Econ 82:370-388

Meeusen W, Van den Broeck J (1977) Efficiency estimation from Cobb-Douglas production functions with composed error. Int Econ Rev 18:435-444

Nin A, Arndt C, Preckel PV (2003) Is agricultural productivity in developing countries really shrinking? New evidence using a modified nonparametric approach. J Dev Econ 71:395-415

O'Rourke KH, Williamson JG (2005) From Malthus to Ohlin: Trade, industrialisation and distribution since 1500. Journal of Economic Growth 10:5-34 
Pasquali P (2020) Migration regimes and the governance of citizenship: a comparison between legal categories of migration in China and in the European Union. J Chin Gov. https://doi.org/10. 1080/23812346.2020.1791505

Raiser M (1998) Subsidising inequality: economic reforms, fiscal transfers and convergence across Chinese provinces. J Dev Stud 34:1-26

Ranis G, Fei JC (1961) A theory of economic development. Am Econ Rev 51:533-565

Rezitis AN (2010) Agricultural productivity and convergence: Europe and the United States. Appl Econ 42:1029-1044

Ruan J, Gopinath M, Buccola S (2008) Welfare effects of technological convergence in processed food industries. Am J Agric Econ 90:447-462

Ruttan VW (2002) Productivity growth in world agriculture: sources and constraints. J Econ Perspect 16:161-184

Sala-i-Martin XX (1996) Regional cohesion: evidence and theories of regional growth and convergence. Eur Econ Rev 40:1325-1352

Schmidt P, Sickles RC (1984) Production frontiers and panel data. J Business Econ Stat 2:367-374

Schmidt TD, Jensen PS, Naz A (2018) Agricultural productivity and economic development: the contribution of clover to structural transformation in Denmark. J Econ Growth 23:1-40

Shang C (2015) Essays on the use of duality, robust empirical methods, panel treatments, and model averaging with applications to housing price index construction and world productivity growth. Dissertation, Rice University

Sickles RC (2005) Panel estimators and the identification of firmspecific efficiency levels in parametric, semiparametric and nonparametric settings. J Econ 126:305-334
Strulik H, Weisdorf J (2008) Population, food, and knowledge: a simple unified growth theory. J Econ Growth 13:195

Thirtle C, Lin L, Piesse J (2003) The impact of research-led agricultural productivity growth on poverty reduction in Africa, Asia and Latin America. World Development 31:1959-1975

Villoria NB (2019) Technology spillovers and land use change: empirical evidence from global agriculture. Am J Agric Econ 101:870-893

Vollrath D (2011) The agricultural basis of comparative development. J Econ Growth 16:343-370

Wang H-J, Ho C-W (2010) Estimating fixed-effect panel stochastic frontier models by model transformation. J Econ 157:286-296

Wang SL, Huang J, Wang X, Tuan F (2019) Are China's regional agricultural productivities converging: How and why? Food Policy 86:101727

Wang X, Yamauchi F, Huang J (2016) Rising wages, mechanization, and the substitution between capital and labor: evidence from small scale farm system in China. Agric Econ 47:309-317

World Bank (2007) World Development Report 2008: Agriculture for Development. World Bank Group. https://openknowledge. worldbank.org/handle/10986/5990

Young AT, Higgins MJ, Levy D (2008) Sigma convergence versus beta convergence: evidence from US county-level data. J Money Credit Banking 40:1083-1093

Yu X (2012) Productivity, efficiency and structural problems in Chinese dairy farms. China Agric Econ Rev 4:168-175

Zhang S, Wang S, Yuan L, Liu X, Gong B (2020) The impact of epidemics on agricultural production and forecast of COVID-19. China Agric Econ Rev 12:409-425 